\title{
Peremptory Challenges Should Be Abolished: A Trial Judge's Perspective
}

\author{
Morris B. Hoffman $\dagger$
}

\section{INTRODUCTION}

Although reports of the death of the peremptory challenge have been greatly exaggerated, ${ }^{1}$ the debate about its continuing vitality rages on, both in the academy and in the courts. ${ }^{2}$ After

$\dagger$ District Court Judge, Second Judicial District (Denver), State of Colorado. I want to thank three students from the University of Denver Law School-Michael Greenfeig, Gregg Klingenberg, and Christopher McGee-whose help in accessing the shiny wonders of computer research, as well as the dusty wonders of old-fashioned library research, was invaluable to my preparation of this article. The views expressed here are of course my own, and do not reflect the views of the Denver District Court or any of my colleagues on that Court.

${ }^{1}$ See, for example, Karen M. Bray, Comment, Reaching the Final Chapter in the Story of Peremptory Challenges, 40 UCLA L Rev 517, 554-564 (1992); James J. Gobert, The Peremptory Challenge-An Obituary, 1989 Crim L Rev 528, 530-33; Jason Hochberg, Peremptory Challenge: An American Relic Like the Model-T Ford and the \$2 Bill, Its Time Has Passed, 10 WTR Crim Just 10 (1996); Brian E. Leach, Comment, Extending Batson v. Kentucky to Gender and Beyond: The Death Knell for the Peremptory Challenge?, 19 SIU L J 381, 401-02 (1995); Michael A. Cressler, Comment, Powers v. Ohio: The Death Knell for the Peremptory Challenge?, 28 Idaho L Rev 349, 353 (1991-92); Keith A. Ward, Comment, "The Only Thing in the Middle of the Road is a Dead Skunk and a Yellow Stripe": Peremptory Challenges-Take 'Em or Leave 'Em, 26 Tex Tech L Rev 1361, 1387-92 (1995); Barbara L. Horwitz, Comment, The Extinction of the Peremptory Challenge: What Will the Jury System Lose By Its Demise?, 61 U Cin L Rev 1391, 1427-39 (1993); Brian Wilson, Case Note, Batson v. Kentucky: Can the "New" Peremptory Challenge Survive the Resurrection of Strauder v. West Virginia?, 20 Akron L Rev 355, 363-64 (1986); Eric N. Einhorn, Note, Batson v. Kentucky and J.E.B. v. Alabama ex. rel. T.B.: Is the Peremptory Challenge Still Preeminent?, 36 BC L Rev 161, 197-200 (1994); Angela J. Mason, Note, Discrimination Based on Religious Affiliation: Another Nail in the Peremptory Challenge's Coffin?, 29 Ga L Rev 493, 536-38 (1995); Patricia F. Kaufman, Note, The Beginning of the End of Peremptory Challenges: Georgia v. McCollum, 112 S. Ct. 2348 (1992), 16 Harv J L \& Pub Policy 287, 293 (1993); Edmund L. Quatmann, Jr., Note, J.E.B. v. Alabama ex. rel. T.B.: The Extension of the Equal Protection Clause to Gender-Based Peremptory Challenges-Is This the End?, 39 SLU L J 1349, 1385-86 (1995); Gary C. Furst, Note, Will the Religious Freedom Restoration Act Be Strike Three Against Peremptory Challenges?, 30 Valp U L Rev 701, 716 (1996). See also that portion of Professor Alschuler's article wonderfully titled The Unconstitutionality of the Peremptory Challenge: Is It Bedtime for Batson?, in Albert W. Alschuler, The Supreme Court and the Jury: Voir Dire, Peremptory Challenges, and the Review of Jury Verdicts, 56 U Chi L Rev 153, 199-211 (1989). To be fair to Professor Alschuler, he doesn't so much predict bedtime for Batson as plead for it.

${ }^{2}$ In the academy, see, for example, Alschuler, $56 \mathrm{U}$ Chi L Rev at 199-211 (cited in note 1); Cheryl G. Bader, Batson Meets the First Amendment: Prohibiting Peremptory Challenges That Violate a Prospective Juror's Speech and Association Rights, 24 Hofstra 
experiencing peremptory challenges firsthand for six years as a trial judge in a state court of general jurisdiction, I now add my small voice to the chorus calling for abolition.

I am a late convert. It has taken a shift of reference frame from bar to bench, and then from civil bench to criminal bench, for me to reach the point where I now believe that the benefits of the peremptory challenge system are outweighed by the damage which that system causes to the most basic principles of an impartial jury.

I am a reluctant convert. My reluctance springs from a deep respect for the traditions surrounding the right to a jury trial, and a personal conviction, confirmed by my experience on the

L Rev 567, 583-86 (1996); Roberta K. Flowers, Does It Cost Too Much? A "Difference" Look at J.E.B. v. Alabama, 64 Fordham L Rev 491, 530-33 (1995); Katherine Goldwasser, Limiting a Criminal Defendant's Use of Peremptory Challenges: On Symmetry and the Jury in a Criminal Trial, 102 Harv L Rev 808, 839 (1989); Brent J. Gurney, Note, The Case for Abolishing Peremptory Challenges in Criminal Trials, 21 Harv CR-CL L Rev 227, 244-56 (1986); Robert L. Harris, Jr., Note, Redefining the Harm of Peremptory Challenges, 32 Wm \& Mary L Rev 1027, 1052-64 (1991); Nancy S. Marder, Beyond Gender: Peremptory Challenges and the Roles of the Jury, 73 Tex L Rev 1041, 1114-36 (1995); Kenneth J. Melilli, Batson in Practice: What We Have Learned About Batson and Peremptory Challenges, 71 Notre Dame L Rev 447, 502-03 (1996); Jere W. Morehead, When a Peremptory Challenge is No Longer Peremptory: Batson's Unfortunate Failure to Eradicate Invidious Discrimination From Jury Selection, 43 DePaul L Rev 625, 636-41 (1994); Robert M. O'Connell, Note, The Elimination of Racism from Jury Selection: Challenging the Peremptory Challenge, 32 BC L Rev 433, 483-85 (1991); William T. Pizzi, Batson v. Kentucky: Curing the Disease but Killing the Patient, 1987 S Ct Rev 97, 123-56; Barbara D. Underwood, Ending Race Discrimination in Jury Selection: Whose Right Is It, Anyway?, 92 Colum L Rev 725, 760-74 (1992).

In the courts, the Supreme Court continues its struggle to find a sensible and constitutionally principled way to prevent Batson from swallowing peremptory challenges entirely. See text accompanying notes 132-61. Judges at all levels, in reported opinions, commentary, and surveys, have begun to articulate discontent not only with Batson but with the larger question of peremptory challenges themselves. See, for example, Alen $v$ State, 596 S2d 1083, 1086-95 (Fla Dist Ct App 1992) (Hubbart concurring) (arguing in favor of abolition); Davis v State, $333 \mathrm{Md} 27,633$ A2d 867, 876 (1993) (referring to academic and judicial debates on elimination of peremptory challenges); Gilchrist $v$ State, $97 \mathrm{Md}$ App 55, 627 A2d 44, 55-56 (Md Ct Spec App 1993) (Wilner concurring) (recommending reconsideration of peremptory challenges altogether); State $v$ Wacaser, 794 SW2d 190, 19699 (Mo 1990) (Robertson concurring) (expressing support for abolition of peremptory challenges). Perhaps the most remarkable of these judicial criticisms is Judge Bellacosa's concurrence in Bolling, in which he, joined by two of his colleagues on the New York Court of Appeals, pleads with the New York legislature to abolish peremptory challenges entirely. People $v$ Bolling, 79 NY2d 317, 582 NYS2d 950, 960 (1992) (Bellacosa concurring). No doubt the most comprehensive criticism is Judge Broderick's article in the Temple Law Review. Raymond J. Broderick, Why the Peremptory Challenge Should Be Abolished, 65 Temple L Rev 369, 416-23 (1992).

A 1995 survey of federal trial judges disclosed that a hefty 15 percent of all respondents favored the abolition of peremptory challenges. Christopher E. Smith and Roxanne Ochoa, The Peremptory Challenge in the Eyes of the Trial Judges, 79 Judicature 185, 188, Table 3 (Jan-Feb 1996). An additional 19 percent favored some modification of current rules or practices regarding the peremptory challenge. Id. 
bench, that jury trials really do work. ${ }^{3}$ For me, something must be seriously wrong if a practice as widespread and time-honored as the peremptory challenge is to be discarded. Something is seriously wrong.

Criticisms and defenses of Batson $v$ Kentucky $y^{4}$ are legion, and I do not intend to cover that well worn ground. ${ }^{5}$ Nor do I intend to enter directly into the empirical debate (what effect peremptory challenges actually have on case outcomes), ${ }^{6}$ the technical debate (what effect abolition would have on other phases of jury

${ }^{3}$ In this sense, I have come to my skepticism about the peremptory challenge from a very different direction than those commentators who question the utility of the jury trial itself, especially the civil jury trial, and who see the peremptory challenge as just another inexplicable bell and whistle on an already irrational contraption. These criticisms have accelerated of late as part of the general handwringing about tort reform. See, for example, Stephen Daniels, The Question of Jury Competence and the Politics of Civil Justice Reform: Symbols, Rhetoric and Agenda-Building, 52 L \& Contemp Probs 269, 279-308 (Autumn 1989) (describing the public attack on civil juries). In fact, our ambivalence about the jury trial has a long and storied past. Hans Zeisel, The Debate Over the Civil Jury in Historical Perspective, 1990 U Chi Legal F 25, 27-29 (1990) (describing a debate on jury size). See also Julia E. Johnsen, ed, Jury System (H.W. Wilson 1929). I do not pretend that the jury trial is always an efficient or even rational mechanism, but my experience suggests that it is generally a just one, both in civil and criminal cases. In any event, the jury trial is a constitutional given; the peremptory challenge is not.

I do not entirely share Professor Marder's powerfully developed view that the constitutional test for peremptory challenges should shift from the Fourteenth Amendment to the Sixth Amendment. Nor do I agree with her broad perception of the jury as a public institution struggling with complex issues of policy. See Marder, 73 Tex L Rev at 1095, 1125-36 (cited in note 2). Although I agree that peremptory challenges must one day face the music of the Sixth Amendment, and perhaps even fail because they nullify the fair cross-section requirement, see text accompanying notes $230-35$, I have a trial judge's rather myopic view of the trial process. Trials decide single cases between specific litigants. We need impartial juries, not to vindicate the participatory interests of prospective jurors, but rather to decide individual cases justly.

476 US 79 (1986).

- Most of the commentaries listed in notes 1 and 2 are, fundamentally, examinations of Batson and its progeny. They boil down to some combination of these basic perspectives: (1) Batson is an uncontrollable beast that eventually, but lamentably, will destroy the peremptory challenge; (2) the peremptory challenge is the beast, and Batson will eventually slay the beast; and (3) Batson is a sensible limitation on peremptory challenges, though from time to time it may need some difficult fine-tuning. My own views have evolved from perspective number 3 into perspective number 2.

' See, for example, Frederick L. Brown, Frank T. McGuire, and Mary S. Winters, The Peremptory Challenge as a Manipulative Device in Criminal Trials: Traditional Use or Abuse, 14 New Eng L Rev 192 (1978); Gobert, 1989 Crim L Rev at 531 (cited in note 1) (finding that the use of peremptory challenges does not increase a defendant's chances of acquittal or lower the chances of conviction); Julie Vennard and David Riley, The Use of Peremptory Challenge and Stand by of Jurors and their Relationship to Trial Outcome, 1988 Crim L Rev 731; Hans Zeisel and Shari Seidman Diamond, The Effect of Peremptory Challenges on Jury and Verdict: An Experiment in a Federal District Court, 30 Stan L Rev 491, 507 (1978) (finding the effects of peremptory strikes to be minimal on jury verdicts in a majority of cases). Some of the most recent empirical studies on the efficacy, or lack of efficacy, of the peremptory challenge are collected at Marder, 73 Tex L Rev at 1080-83 $\mathrm{nn}$ 156-64 (cited in note 2). 
selection, including, in particular, challenges for cause), ${ }^{7}$ or the constitutional debate (whether Batson and its progeny compel the conclusion that peremptory challenges are unconstitutional). ${ }^{8}$ Instead, I want to try to articulate how, as a provincial trustee of this institution of the jury trial, I have come to realize that the very notion of peremptory challenges is in hopeless conflict with our ideals of what an impartial jury is and how it should be selected.

In assessing this problem, I want to begin by considering the history of the peremptory challenge and in particular by examining the idea that the peremptory challenge is fundamentally flawed, both because it is rooted in the now meaningless and quite undemocratic concept of royal infallibility, and because it was invented two hundred years before the notion of jury impartiality. Apart from these defects in origin, I also want to examine the proposition that the conditions which gave rise to, and may have supported the continuation of, the peremptory challenge simply do not exist today. Finally, with these historical perspectives in mind, I want to consider the various ways in which the peremptory challenge is inimical to our most fundamental precepts of an impartial jury.

\section{THE History OF THE PEREMPtory Challenge}

There has been a kind of mythic genealogy constructed about the peremptory challenge. To be sure, the idea of the peremptory challenge is old, but it is not nearly as old, deep, or widespread as the notion of the jury itself. Its ancient association with the right to trial by jury has cloaked it with a presumption of legitimacy bordering on, but never quite reaching, the constitutional. Although there is no shortage of academic and judicial generalizations about the importance of the peremptory challenge, ${ }^{9}$ there

7 See, for example, Bray, Comment, 40 UCLA L Rev at 556-58 (cited in note 1); Marder, 73 Tex L Rev at 1080-83 (cited in note 2).

* See, for example, Bolling, 582 NYS2d at 958-60 (Bellacosa concurring) (arguing that the peremptory challenge can be used as a tool of invidious discrimination); Alschuler, $56 \mathrm{U}$ Chi L Rev at 199-214 (cited in note 1) (suggesting that the exercise of peremptory challenges is at odds with the Equal Protection Clause); Broderick, 65 Temple L Rev at 399-410 (cited in note 2) (suggesting that peremptory challenges are at odds with values behind the Equal Protection Clause, and the Sixth and Thirteenth Amendments). See also notes 142 and 143 and accompanying text.

- No doubt the most often-quoted generalization is Blackstone's description of the peremptory challenge as "a provision full of that tenderness and humanity to prisoners, for which our English laws are justly famous." William M. Blackstone, 4 Commentaries on the Laws of England *353 (W.L. Dean 1846). Less often-quoted is the immediately preceding sentence, which describes the peremptory challenge as "an arbitrary and capricious species of challenge." Id. Perhaps no two sentences so elegantly capture the am- 
have been remarkably few efforts to articulate precisely why the peremptory challenge is so important. Indeed, when pressed to do more than simply pontificate on the generalized importance of the peremptory challenge, the Supreme Court has consistently and unflinchingly held that the peremptory challenge is neither a constitutionally necessary component of a defendant's right to an impartial jury, ${ }^{10}$ nor even so fundamental as to be part of federal common law. ${ }^{11}$ Moreover, when a trial court erroneously interferes with a party's peremptory challenges, that interference is often deemed harmless. ${ }^{12}$ Perhaps there has never been a legal "right" so praised in the abstract, yet so rejected when the constitutional, common law, and harmless error rubber actually meets the road.

One of the keys to understanding this ambivalence, and to recognizing that the peremptory challenge is not only not required for an impartial jury but may in fact be in conflict with it, lies in its rather unusual history.

\section{A. Pre-English History}

The notion of a jury-a group of people brought together to resolve disputes between other people - is as old as civilization itself. Indeed, mythology is laced with examples of juries, both mortal and immortal, deciding disputes between gods, disputes between mortals, and even disputes between gods and mortals. ${ }^{13}$

bivalence and downright schizophrenia with which peremptory challenges have been viewed throughout their history.

See text accompanying notes 81-82.

"The prosecutor's entitlement to peremptory challenges is not grounded in federal common law, though a defendant's probably is. See text accompanying notes 83-85.

12 See text accompanying notes 162-72.

${ }^{23}$ There are several Norse and Greek myths involving trial by jury. The whole of the Norse mythic universe was ruled by a jury of sorts-twelve gods, each of whom held a "judgment seat," who took counsel together. Peter Andreas Munch, Norse Mythology: Legends of Gods and Heroes 5-6 (New York 3d ed 1954). Odin, the supreme Norse god and foreman, so to speak, of this ruling jury, ordained twelve demigods to preside over more mundane earthly disputes. Lloyd E. Moore, The Jury: Tool of Kings, Palladium of Liberty 4 (Anderson 2d ed 1988). The Greek god Ares was tried for the murder of Poseidon's son by a jury of twelve gods. They hung six to six. Id at 1; Alexander S. Murray, The Manual of Mythology 237 (New Hollywood 1993). The first Greek mortal tried by a mythical jury appears to have been Orestes, the son of Agamemnon and the brother of Electra. He was tried for the murder of his mother, whom he caused to be killed in a conspiracy with Electra and at the irresistible urgings of Apollo. Athena convened a jury of twelve mortals to hear the case against Orestes (who was defended, ably we must assume, though with no small conflict of interest, by Apollo himself). Again, the jury hung six to six. Moore, The Jury at 1. The Orestes trial, as part of the broader Agamemnon myth, was retold by Aeschylus in his play The Oresteia and by Euripedes in his play Orestes. See Aeschylus, Oresteia (Cambridge 1979) (Frederic Raphael and Keneth Macleish, trans); and Euripedes, Orestes (Bryn Mawr 1984) (Thomas M. Falkner, trans). 
Though never the preeminent method of ancient dispute resolution, juries in some form or another were known in Ancient Egypt, Mycenae, Druid England, Greece, Rome, Viking Scandinavia, the Holy Roman Empire, and even Saracen Jerusalem before the Crusades. ${ }^{14}$ Many of these forms of juries appear to have arisen quite independently from one another, ${ }^{15}$ confirming that the idea of the jury resides deep in the human psyche.

By contrast, the notion of a peremptory challenge-the right of a disputant to veto an otherwise qualified juror-has a substantially less comprehensive history. There are no myths about peremptory challenges, and nothing like peremptory challenges appears in any ancient jury system until the Roman system described below. ${ }^{16}$ Athenian juries, for example, were composed of qualified citizens randomly selected by lot to serve on a particular case. ${ }^{17}$ Typically, these early Athenian juries-called "dikasteria"-were very large, ranging in size from two hundred to fifteen hundred members, and those who were picked served, ${ }^{18}$ with no recorded mechanism for the litigants to intervene in their selection.

The Athenian dikasteria were later copied by the Romans, who called their jurors "Judices" and used them for their senatorial trials. ${ }^{19}$ Roman Judices were the first ancient jurors to be selected by anything even remotely resembling the modern peremptory challenge. For all but fifty years during a particularly egalitarian time in the first century, the Judices were chosen exclusively from the senatorial class. ${ }^{20}$ Once each year the Senate would designate which of its members would serve as prospective jurors in all senatorial trials for that year. From this group, eighty-one senators would be selected by lot for any particular

14 Moore, The Jury at 1-20 (cited in note 13); John Proffatt, A Treatise on Trial By Jury, Including Questions of Law and Fact §§ 1-10 (Rothman 1986); Theodore F.T. Plucknett, A Concise History of the Common Law 107-31 (Little, Brown 5th ed 1956).

${ }^{15}$ Moore, The Jury at 4-8 (cited in note 13). See also notes 27 and 28 and accompanying text.

${ }^{16}$ See text accompanying notes 19-21.

${ }^{17}$ Douglas M. MacDowell, The Law In Classical Athens 33-40 (Cornell 1978); Moore, The Jury at 2 (cited in note 13) (citizens had to be over thirty years old with no debt to the state).

${ }^{18}$ Moore, The Jury at 2 (cited in note 13); Proffatt, Trial by Jury $\$ 6$ (cited in note 14).

${ }^{19}$ Moore, The Jury at 3 (cited in note 13). Senatorial trials were just one type of Roman trial, and they were generally limited to political cases, disputes between senators, particularly scandalous crimes, and other matters of special imperial significance. The bulk of day-to-day Roman trials were non-jury trials decided by individual prefects or other imperial officials. See generally Peter Garnsey, Social Status and Legal Privilege in the Roman Empire 19-25 (Oxford 1970).

${ }^{20}$ From 122 B.C. to 70 B.C., the Judices were drawn not only from the senatorial class but also from the equestrian class. Moore, The Jury at 3 (cited in note 13). 
trial. Each litigant in that trial could challenge fifteen prospective jurors, leaving a jury of fifty-one. ${ }^{21}$

With the notable exceptions of the dikasteria and Judices, it appears that the function of most ancient juries was a limited one: to investigate and then report suspected criminal activity, with the ultimate guilt or innocence of the accused to be determined later, by non-jury methods. ${ }^{22}$ These early juries thus served both an investigatory and accusatory function, ${ }^{23}$ and of course that role continues today in our institution of the grand jury. Even as jurors began over time to play an increasing role in the actual trial, their role remained a somewhat complex mixture of accuser and actual witness. Jurors were the ruler's watchdogs for criminal behavior, and they were selected by the ruler's agents precisely because they may have had personal knowledge of the alleged crime, or, more often, personal knowledge of the accused or of the victim. This notion of jurors as witnesses, as opposed to jurors as independent judges of the credibility of trial witnesses ${ }^{24}$ was so deeply ingrained in the ancient jury that it remained part of the English jury system until late in the fourteenth century. ${ }^{25}$ The concept of the ancient juror's limited role as witness may explain the absence of any ancient practices akin to peremptory challenges, with the exception, of course, of the selection of the Roman Judices.

\section{B. The Peremptory Challenge in England}

Even though the selection method of the Judices bears some resemblance to the modern peremptory challenge, there is little evidence that the concept of the Judices spread from Rome to England. ${ }^{26}$ On the contrary, although there was once a great debate on the question, ${ }^{27}$ it is now generally accepted that the Eng-

${ }^{21}$ Id. This number of eighty-one for the initial panel varied somewhat over time, ranging from fifty-one to eighty-one. Id.

${ }_{2}^{2}$ William Forsyth, History of Trial by Jury 106 (Burt Franklin 2d ed 1971); Robert von Moschzisker, Trial by Jury \$§ 66-67 at 53-57 (Bisel 2d ed 1930); Sir Frederick Pollock and Frederic William Maitland, 2 The History of English Law Before the Time of Edward I 622-23 (Little, Brown 2d ed 1899); Proffatt, Trial by Jury \$\$ 27-29 (cited in note 14).

${ }^{23}$ Moore, The Jury at 14 (cited in note 13).

${ }^{24}$ Moore, The Jury at 40 (cited in note 13 ).

2 Forsyth, History of Trial at 125-38 (cited in note 22); Moore, The Jury at 56 (cited in note 13); Proffatt, Trial by Jury \$§ 29-30 (cited in note 14); von Moschzisker, Trial by Jury $\$ 68$ at 57-58 (cited in note 22). Indeed, very early English jurors may simply have decided which of the various ordeals a defendant should face. Plucknett, $A$ Concise History of the Common Law at 120 (cited in note 14).

${ }^{26}$ Moore, The Jury at 3-4 (cited in note 13) (suggesting slight possibility of a residual Greek and Roman influence).

" The debate appears to have begun in the seventeenth century, when the jury be- 
lish probably did not inherit the jury trial from the Romans, and that the jury was unknown to the English until the Conquest. ${ }^{28}$ Most likely, trial by jury was introduced into England by William the Conqueror, who added it to the three basic trial methods already practiced in England and on the Continent since Charlemagne: trial by compurgation, trial by battle, and trial by ordeal. ${ }^{29}$ Trial by compurgation (in which the winning litigant was the one who could bring a designated number of respected people to court willing to swear to the truth of his oath) ${ }^{30}$ was generally limited in post-Conquest England to minor civil disputes and misdemeanor criminal offenses. ${ }^{31}$ Trial by battle, favored by the

came an idealized anti-royalist institution. Some historians, amateur and professional alike, had political motives to trace the English jury to democratic roots in Greece and Rome or, at the very least, to quasi-democratic roots in Anglo-Saxon villages before the Conquest, rather than to royal ancestors on the Continent. See, for example, Moore, The Jury at 3-4, 18-19 (cited in note 13) (noting possibility that jury may have had Roman or Frankish influence). See also von Moschzisker, Trial by Jury $\$ \$$ 6-10 at 6-11 (cited in note 22); Pollock and Maitland, 2 History of English Law at $604 \mathrm{n} 1$ (cited in note 22).

2 The English jury most likely traces its immediate origins to Charlemagne's "inquisito" (a type of Frankish jury); thus, neither the idea nor the practice of jury trials probably existed in England before the Conquest. See generally Heinrich Brunner, The Origin of Juries (Berlin 1872) (finding that the English jury had Frankish origins), reported in Moore, The Jury at 13-19 (cited in note 13); John P. Dawson, A History of Lay Judges 118-21 (Harvard 1960); von Moschzisker, Trial by Jury \$\$ 6-10 at 6-11 (cited in note 22). Pollack and Maitland recognized the non-democratic origins of the English jury:

[B]ut for the conquest of England, [the jury] would have perished .... [The] 'palladium of our liberties' is in its origin not English but Frankish, not popular but royal.

Frederick Pollock and Frederic William Maitland, 1 The History of English Law Before the Time of Edward I 141-42 (Little, Brown 2d ed 1899).

${ }^{29}$ Moore, The Jury at 26-30, 41, 123 (cited in note 13); Proffatt, Trial by Jury $\$ \$ 11-20$ (cited in note 14).

$\approx$ Trial by compurgation is also sometimes called the "wager of law." In criminal trials by compurgation, the defendant first took an oath of his innocence, and then he called a designated number of compurgators, or "oath helpers." The number required varied from twelve to forty-eight depending on the seriousness of the charges and on the rank of the defendant and his compurgators. The compurgators did not testify in the modern sense; they merely vouched for the trustworthiness of the defendant's oath of innocence. If the required number and quality of compurgators appeared and vouched for the defendant, he was declared innocent. See generally von Moschzisker, Trial by Jury $\$ \$ 43-45$ at 34-37 (cited in note 22); Moore, The Jury at 27 (cited in note 13).

In civil trials by compurgation, the plaintiff took his oath and called his compurgators. If their numbers, quality, and oaths were sufficient, the burden then passed to the defendant to take his oath and call his compurgators. He was cautioned about the consequences of a false oath, but generally if the defendant swore he was not liable and his oath was supported by a sufficient number and quality of compurgators, judgment was entered for the defendant because the plaintiff usually had the burden of proof. von Moschzisker, Trial by Jury $\$ \S 43-44$ at 34-36 (cited in note 22); Blackstone, 3 Commentaries at $* 343$ (cited in note 9 ).

31 Moore, The Jury at 26-27 (cited in note 13). Even before it fell into disuse, trial by compurgation was not usually available in certain cases-such as those involving official misconduct, suits on debts secured by real property, some types of perjury, and crimes 
Normans, also eventually fell into disuse. ${ }^{32}$ For serious criminal cases or other cases involving important issues, trial by ordeal remained the dispute resolution mechanism of choice (at least the Crown's and the Church's choice, if not the defendant's). ${ }^{33}$ Trial by jury during this period remained exceedingly rare. ${ }^{34}$

"openly committed"-in which the temptation to bribe compurgators was deemed too great. von Moschzisker, Trial by Jury \$§ 46-48 at 37-38 (cited in note 22).

${ }^{2}$ Not only in England, but also throughout medieval northern Europe, Viking traditions of trial by battle, also sometimes called trial by combat, found their way into accepted trial procedures, at least to resolve certain disputes between members of the ruling classes. Blackstone, 3 Commentaries at *337-41 (cited in note 9) (civil); Blackstone, 4 Commentaries at *346-48 (cited in note 9) (criminal); Forsyth, History of Trial at 81 (cited in note 22); von Moschzisker, Trial by Jury $\$ 17$ at 14 (cited in note 22); Plucknett, History of the Common Law at 116 (cited in note 14). As disputing nobles began to be permitted to hire champions in their stead-and perhaps more importantly, as the influence of the Church began to dissolve the sharper pagan edges of Norse traditions-trial by battle became displaced almost entirely by the ordeal. von Moschzisker, Trial by Jury $\$ 56$ at 45-46 (cited in note 22).

${ }_{33}$ The medieval ordeals were not exactly the no-win propositions we might associate with, for example, witch trials of the Inquisition, in which the only two outcomes were death by the ordeal (followed by a post-mortem declaration of innocence) or survival of the ordeal (followed by a declaration of guilt and burning at the stake). Instead, if a defendant survived the trial by ordeal, it was generally a sign of God's intervention, and therefore of innocence, not a sign of demonic possession.

There were three principal English ordeals for serious crimes-hot iron, hot water, and cold water. In the ordeal of hot iron, the accused was required to walk a specified distance carrying a piece of red-hot iron (or in some variations, to walk barefoot and blindfolded over some red-hot surface). If the accused managed to avoid being burned, he was declared innocent. If he was burned, he was declared guilty. In the ordeal of hot water, the accused was required to reach his bare arm into a pail of boiling water and retrieve a stone. Again, he was innocent only if God intervened to protect him from scalding. In the ordeal of cold water, the accused was thrown into a pond or lake, usually after being bound. Once again, he was innocent only if he managed to survive. See generally Blackstone, 4 Commentaries at *337-38 (cited in note 9); von Moschzisker, Trial by Jury $\$ 49$ at 38-39 (cited in note 22).

For less serious crimes, unusual intervention by fate was seen as a sign of guilt, not innocence. Thus, in the ordeal of the consecrated morsel, for example, the accused was required to swallow a piece of bread accompanied by a prayer that he should choke if he were guilty. Blackstone, 4 Commentaries at $* 345$ (cited in note 9); von Moschzisker, Trial by Jury $\$ 50$ at 39-40 (cited in note 22). Although this might appear to our modern humanistic eyes as a rather unchallenging task, in 1194 the Earl of Kent actually choked to death during the ordeal of the consecrated morsel, no doubt extending for many years the public's faith in this mildest of the ordeals. Forsyth, History of Trial by Jury at 68 (cited in note 22); Proffatt, Trial by Jury $\$ 12$ at 16 (cited in note 14).

Finally, although most medieval civil disputes were resolved either by battle, compurgation, or jury, there were a few civil ordeals. For example, in the ordeal of the cross, the opposing litigants were placed next to one another, each facing a cross, with arms outstretched. He lost who dropped his arms first. von Moschzisker, Trial by Jury App 2 at 388 (cited in note 22). Readers who do civil litigation will recognize the spirit of this ordeal in our current discovery practices.

${ }^{3}$ Thomas Andrew Green, Verdict According to Conscience: Perspectives on the English Criminal Trial Jury 1200-1800 11 (Chicago 1985); Moore, The Jury at 39 (cited in note 13). 
Interestingly, it appears that in those rare instances when juries were summoned, they were summoned to decide civil, not criminal, cases. ${ }^{35}$ Indeed, shortly after the Conquest, William himself convened civil juries in every English county to inquire about laws relating to the ownership of lands. ${ }^{36}$ William's son, Henry I, expanded the practice of summoning juries to decide particularly important civil disputes. ${ }^{37}$

In 1166, Henry II proclaimed the Assize of Clarendon, ${ }^{38}$ which established a uniform system of juries, called "assizes," to resolve real property disputes. It also banned trial by compurgation for most felonies, and required most felony prosecutions to proceed by ordeal. ${ }^{39}$ Even after the Assize of Clarendon, which is generally recognized as the first significant historical marker in the development of the English jury system, juries were almost never used in criminal cases, and when they were, they were available to the defendant only for a price. ${ }^{40}$

As for the peremptory challenge, it was unknown at this time. Indeed, by the end of the thirteenth century, when the occasional criminal petit jury was convened after an indictment, the trial was simply presented to the same large number of jurors (twenty-four to eighty-four) who had acted as grand jurors, all of whom were knights selected by the King. ${ }^{41}$ Over time, even as English law reduced the number of grand jurors participating in petit juries, and mechanisms developed for the selection of petit jurors, there is no evidence of any peremptory challenge system in place prior to the Magna Carta.

The Magna Carta did not guarantee the right to a jury, ${ }^{42}$ and it had no effect on the rarity with which juries were summoned. ${ }^{43}$

\footnotetext{
${ }^{35}$ Moore, The Jury at 39 (cited in note 13).

${ }^{35}$ Id at 33 .

${ }^{37} \mathrm{Id}$ at 34

3s The Assize of Clarendon is also sometimes called the Grand Assize. Id.

${ }^{3}$ Id at 37-38; Proffatt, Trial by Jury \$\$ 25-26 at 37-39 (cited in note 14).

${ }^{40}$ Moore, The Jury at 49 (cited in note 13); von Moschzisker, Trial by Jury $\$ 54$ at 4445 (cited in note 22 ).

${ }_{41}^{4}$ Moore, The Jury at 49-50, 53-54 (cited in note 13).

${ }^{2}$ Cap 39 of the Magna Carta prohibited the Crown from imprisoning any free man "unless by the lawful judgment of his peers." J.C. Holt, Magna Carta 327 (Cambridge 1965). Although its meaning has certainly expanded over time to encompass the right to trial by jury, see, for example, Thompson v Utah, 170 US 343, 349-50 (1898), and Blackstone, 4 Commentaries at *349 (cited in note 9), most scholars agree that this reference to "peers" had contemporary feudal connotations only, and was not originally intended to grant the right of trial by jury. As Professor Holt has summarized it:

[Parliament later] interpreted the phrase "lawful judgment of peers" to include trial by peers and therefore to include trial by jury, a process which existed only in embryo in 1215 ... Trial by jury was imposed from above, not sought from below, in the later thirteenth and fourteenth centuries.
} 
Nor, of course, did it address the question of peremptory challenges. But the year 1215 saw an event much more significant to the development of the English jury system than the Magna Carta: Pope Innocent III forbade trials by ordeal. ${ }^{44}$ This ban, which found its way into English law in $1219,{ }^{45}$ left trial by jury as the only practical alternative for deciding serious criminal cases. By all indications, it was in the next fifty years, from 1220 to 1270, that the English jury began to flourish and weave itself into the fabric of the common law. ${ }^{46}$

It was also at some unspecified time in this golden foundational age of the English jury trial that the notion of peremptory challenge appears rather suddenly to have taken root, first in capital cases, and with the Crown having an unlimited number of peremptory challenges. As discussed in more detail below, the Crown's unlimited peremptory challenges were actually challenges for cause, which, because of the doctrine of royal infallibility, were irrebuttably presumed to be well-taken. ${ }^{47}$

In an almost immediate response to these unlimited prosecutorial peremptories, courts began to permit defendants to exercise some peremptories in capital cases. This response was as complete as it was rapid. By 1300 , just thirty to eighty years after prosecutorial peremptory challenges first sprouted in England, it was settled as a matter of common law that in all capital cases the Crown had an unlimited number of peremptory chal-

Holt, Magna Carta at 9 \& n 3 (citations omitted). See also Dawson, A History of Lay Judges at 289-90 (cited in note 28); Plucknett, A Concise History at 24 (cited in note 14).

Some have argued that language in Cap 36 of the Magna Carta ("henceforth nothing shall be given or taken for the writ of inquisition of life or limb, but it shall be given freely, and shall not be denied") actually guarantees the right to jury trial, interpreting the reference to "inquisition" to mean "jury," in the manner directly descendant from the Frankish "inquisitos." Moore, The Jury at 49 (cited in note 13). See also note 28. It seems to me that this suggestion, though clever, is also belied by the sheer rarity of the criminal jury trial throughout the first few decades of the thirteenth century. See note 40 .

${ }^{43}$ Moore, The Jury at 48-50 (cited in note 13).

"This pronouncement was contained in Pope Innocent III's Fourth Lateran Council. Plucknett, A Concise History at 118 (cited in note 14). The ordeal seems to have fallen into theological disfavor not because the clergy thought the affairs of man too important to be judged by such processes, but rather quite the contrary. As Proffatt has put it, "[t]he clergy had never given their unqualified assent to the ordeal; they had been the means of its gradual disuse, as they deemed it an impious reference to Heaven." Proffatt, Trial by Jury $\$ 28$ at 41-42 (cited in note 14) (citation omitted). In addition, some reform-minded clergymen objected to the ordeal's potential for corruption, especially given the fact that one noteworthy priest candidly admitted that he felt a moral duty to assist in achieving a "correct" result. Plucknett, $A$ Concise History at 114-15 (cited in note 14).

4 Plucknett, $A$ Concise History at 119 \& n 1 (cited in note 14).

4. Professor Green has described the fifty years following the Assize of Clarendon in 1166 as "the foundation period of the English common law." Green, Verdict According to Conscience at 11 (cited in note 34).

${ }^{4}$ See text accompanying notes 173-82. 
lenges and the defendant had thirty-five. ${ }^{48}$ Although most felonies in this period were punishable by death, ${ }^{49}$ there is also some indication that peremptory challenges may have been permitted in the rare non-capital felony case as well. ${ }^{50}$

But these early stirrings of what eventually developed into the modern peremptory challenge are far from clear. Even after defendants were extended the royal prerogative of challenging jurors without having to state why, the early English peremptory challenge may actually have been a hybrid of what today we call the peremptory challenge and the challenge for cause. Some commentators have suggested that in small English villages and towns, where lawyers, judges, and jurors all knew each other well, and might even have known non-gentried defendants, the so-called peremptory challenge may have been simply a shorthand way of challenging a juror whom all participants recognized was actually disqualified for cause. ${ }^{51}$ If these early peremptory challenges were in fact a kind of unstated challenge for cause, then they had nothing whatever to do with the modern idea of eliminating jurors with hidden biases. On the contrary, thirteenth-century jurors were excused for biases so obvious that they needed no articulation.

This characterization is certainly consistent with the idea that in the beginning the Crown's unlimited peremptory challenges were in fact challenges for cause made by agents of a supposedly infallible King. ${ }^{52}$ Thus, these early hybrid peremptories

\footnotetext{
${ }^{49}$ Proffatt, Trial by Jury $\$ 155$ at 207 (cited in note 14).

${ }^{49}$ Blackstone, 4 Commentaries at *98 (cited in note 9). Dickens lamented that, even as late as the French Revolution, English law imposed the death sentence for virtually every offense:

[P]utting to death was a recipe much in vogue with all trades and professions, and not least of all with Tellson's [Bank]. Death is Nature's remedy for all things, and why not Legislation's? Accordingly, the forger was put to Death; the utterer of a bad note was put to Death; the unlawful opener of a letter was put to Death; the purloiner of forty shillings and six pence was put to Death; the holder of a horse at Tellson's door, who made off with it, was put to Death; the coiner of a bad shilling was put to Death; the sounders of three-fourths of the notes in the whole gamut of Crime were put to Death.

Charles Dickens, A Tale of Two Cities 62 (Signet 1960).

${ }^{50}$ This point was made by the Supreme Court in Swain v Alabama, 380 US 202, 212 n 9 (1965).

${ }^{51}$ Alschuler, 56 U Chi L Rev at 165 n 51 (cited in note 1). Even though English jurors in this time period did not have to be "impartial" in the modern sense, see text accompanying notes $22-25$ and $182-85$, there was a well established if somewhat limited doctrine of disqualification for cause, grounded primarily in a juror's relationship to any litigant by blood, marriage, or economic interest. Jon M. Van Dyke, Jury Selection Procedures: Our Uncertain Commitment to Representative Panels 141 (Ballinger 1977).

${ }^{52}$ See text accompanying notes $173-78$.
} 
may well have been challenges for cause in both of these sensesexercised first by prosecutors still cloaked in the garb of royal infallibility, and later by prosecutors and defense lawyers who knew the prospective jurors so well that their unspoken assertions of cause went unchallenged.

Another factor muddying the early history of the peremptory challenge is that even though it was firmly rooted in the common law by no later than 1305, when Parliament first officially recognized it (though, ironically, by outlawing its use by the Crown) ${ }^{53}$ the actual use of the peremptory challenge in English criminal trials appears almost nonexistent over its entire seven-hundredyear history, and rare even at its zenith. It was so rare, in fact, that some scholars believe that for its first five hundred years the peremptory challenge was simply unavailable in ordinary criminal trials. ${ }^{54}$ An exhaustive examination of English jury records in the last half of the fourteenth century uncovered no trace of any peremptory challenges. ${ }^{55} \mathrm{~A}$ similar study covering the eighteenth century reported that even at that late date peremptory challenges were "rarely used." ${ }^{\text {"56 }}$ Even in modern times, when perceived abuses eventually led to the complete abolition of the peremptory challenge in England ${ }^{57}$ its use, as late as 1979, had been described as no more frequent than one in seven trials, rarely with more than one peremptory challenge in a case. ${ }^{58}$ The historical summary that follows, therefore, must be understood in this overarching context: the actual exercise of the English peremptory challenge has always been a rare occurrence.

It was intolerable to Parliament that the Crown should not only continue its practice of handpicking all prospective jurors, but then be given an unlimited number of peremptory challenges to boot. In 1305, Parliament outlawed entirely the Crown's right to any peremptories, while leaving intact a criminal defendant's common law right to thirty-five. ${ }^{59}$ But the King's courts quickly

\footnotetext{
${ }^{53}$ See text accompanying note 59.

-4 J.B. Post, Jury Lists and Juries In The Late Fourteenth Century, in J.S. Cockburn and Thomas A. Green, eds, Twelve Good Men and True: The Criminal Trial Jury in England 1200-1800 71 (Princeton 1988).

"s. Id.

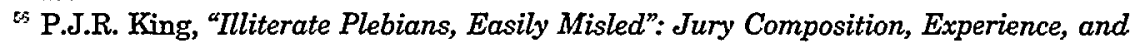
Behaviour in Essex, 1735-1815, in Cockburn and Green, Twelve Good Men at 277-78 (cited in note 54).

${ }^{67}$ See text accompanying notes 66-67.

${ }^{63} \mathrm{John}$ Baldwin and Michael McConville, Jury Trials 92-93 (Clarendon 1979). The modern use of peremptory challenges in London may have been somewhat more frequent than in other parts of England. Id at $93 \mathrm{n} 15$.

${ }^{69}$ See Blackstone, 4 Commentaries at *353 (cited in note 9), citing Ordinance for Inquests, 33 Edw 1 (1305) (Eng). See also Forsyth, History of Trial at 192 (cited in note 22).
} 
sidestepped this law by adopting a common law procedure called "standing aside," under which the Crown's prosecutors could direct any number of prospective jurors to "stand aside" pending selection from all the remaining jurors. If, after each side had exercised all its challenges for cause and the defendant had exercised his peremptories, the number of remaining jurors was insufficient to seat a jury, then and only then would the prospective jurors who were standing aside be recalled. Thus, for all practical purposes, the Crown retained its right to an unlimited number of peremptory challenges. ${ }^{60}$

From 1305 forward, the number of peremptory challenges allowed in English criminal trials steadily decreased. A defendant's peremptories were reduced from thirty-five to twenty in $1530,{ }^{61}$ to seven in $1948,{ }^{62}$ to three in $1977,{ }^{63}$ and were eliminated entirely in $1989 .{ }^{64}$ Although the Crown's right to ask jurors to stand aside remained theoretically available until 1989, it is clear that the standing aside procedure was just as rare, and perhaps rarer, than the defendant's exercise of peremptory challenges. ${ }^{65}$

After a series of highly publicized criminal trials in the $1980 \mathrm{~s}$, in which defense counsel's use of the peremptory challenge was widely seen as abusive, Parliament abolished all peremptory challenges effective January $5,1989 .{ }^{66}$ Perhaps nothing is more telling of the restrained manner in which the English have exercised the peremptory challenge than the fact that in the most publicized of these trials, the Cyprus spy trial, all seven defendants pooled their peremptory challenges and exercised a grand total of seven. ${ }^{67}$

${ }^{50}$ Proffatt, Trial by Jury $\S 160$ at 212-13 (cited in note 14).

${ }^{61} 22$ Hen 8, ch 14 § 6 (1530) (Eng). See also 6 Geo 4, ch 50 \$ 29 (1825).

c2 $11 \& 12$ Geo 6 , ch 58 \& 35 (1948).

${ }^{63}$ The Criminal Law Act, 1977, ch $45 \S 43$ (Eng).

es The Criminal Justice Act, 1988, ch 33 \$ 118(1) (Eng).

${ }^{6}$ Baldwin and McConville, Jury Trials at $93 \mathrm{n} 15$ (cited in note 58).

${ }^{65}$ The Criminal Justice Act, 1988, ch 33 \& 118(1) (Eng). That same year, the Attorney General also abolished the practice of standing aside, except in extraordinary circumstances. See Peter Allsop, ed, Current Law Statutes Annotated 33:139-40 (Sweet \& Maxwell 1988).

${ }^{67}$ Broderick, 65 Temple L Rev at 373 n 17 (cited in note 2), quoting Sean Enright, Reviving the Challenge for Cause, New L J 9 (Jan 6, 1989):

[Abolition of the peremptory challenge was] the result of a sustained campaign in Parliament and in the press alleging that defence counsel were systematically abusing it. In multi-handed trials, it was said, counsel were pooling challenges to "pack" juries with individuals who were likely to acquit. The Cyprus spy trial was often cited as an example. In that instance seven jurors were challenged by defence counsel acting together. The jury, all young and male, acquitted all seven defendants. This case more than any other represented a watershed in the campaign to 


\section{The Peremptory Challenge in the United States}

Peremptory challenges have fared much better in this country than in England. Most American colonial courts accepted the English common law practice of giving a criminal defendant some peremptory challenges. ${ }^{68}$ The colonial courts, however, disagreed on whether the prosecution should be given any peremptory challenges, whether by "standing aside" or otherwise. Some colonies permitted an unlimited number of prosecution peremptories, others allowed none. ${ }^{69}$

A defendant has no constitutional right to peremptory challenges, ${ }^{70}$ and indeed the peremptory challenge was not the subject of any reported discussion by the framers, formal or informal. Article III, Section 2 of the Constitution secures the right to a jury in all federal criminal trials, ${ }^{71}$ but makes no mention of the peremptory challenge. There is no record of any discussion of the peremptory challenge in the context of Article III, Section 2, either prior to or during ratification. Indeed, there was surprisingly little discussion of the right to jury trial itself, let alone peremptory challenges. Randolph's original draft of Article III had no provision guaranteeing either criminal or civil juries. ${ }^{72}$ The current provision guaranteeing criminal juries was added by committee, and was accepted at the convention with no recorded debate or dissent. ${ }^{73}$ Although there was a great deal of debate on the question of judicial review of jury verdicts, ${ }^{74}$ and also on the question of whether the federal venire should be drawn, as Article III, Section 1, now provides, from a unit as large as a whole state, ${ }^{75}$ the only significant pre-ratification discussion of the right to trial by jury was Hamilton's explanation in Federalist 83 for

abolish the challenge, even though critics overlooked the fact that the entire jury panel summoned for the trial had been vetted for the prosecution by Special Branch and MI5.

${ }^{63}$ Van Dyke, Jury Selection Procedures at 148 (cited in note 51).

${ }^{69}$ Id at 148-49, $171 \mathrm{n} 46$.

To See text accompanying notes 81-82.

${ }^{7}$ US Const, Art III, \$ 2, cl 3 provides:

The Trial of all Crimes, except in Cases of Impeachment, shall be by Jury; and such Trial shall be held in the State where the said Crimes shall have been committed; but when not committed within any State, the Trial shall be at such Place or Places as the Congress may by Law have directed.

${ }^{72}$ Saul K. Padover, To Secure These Blessings 419 (Washington Square 1962).

${ }^{73}$ Id.

"See, for example, Federalist 81 (Hamilton), in Clinton Rossiter, ed, The Federalist Papers 489-90 (Mentor 1961); Van Dyke, Jury Selection Procedures at 7 (cited in note 51).

${ }^{75}$ Van Dyke, Jury Selection Procedures at 7 (cited in note 51). See also US Const, Art III, $\S 1$. 
why Article III, Section 2, secures the right to jury only in criminal cases and not civil cases. ${ }^{76}$

It was not until the Sixth Amendment was proposed that juror challenges began to be discussed by the framers, although even those discussions were hardly extensive, and they all appear to have been limited to the challenge for cause. At least one early draft of the Sixth Amendment expressly provided that a defendant had a right to challenges for cause. ${ }^{77} \mathrm{In}$ arguing that this specific reference should be deleted, Madison himself took the position that such a reference was unnecessary because the challenge for cause was inherent in the concept of an impartial jury. ${ }^{78}$ Others, including Patrick Henry, denounced the proposal to delete the reference to challenges for cause. ${ }^{79}$ In the end, of course, it was deleted from the final version of the Sixth Amendment. ${ }^{80}$ 74).

${ }^{76}$ Federalist 83 (Hamilton), in Rossiter, ed, Federalist Papers at 495-99 (cited in note

"Valerie P. Hans and Neil Vidmar, Judging the Jury 37 (Plenum 1986), quoting the very first draft of the Sixth Amendment, which provided in pertinent part that the right to an impartial jury would include "the right of challenge and other accustomed requisites."

${ }^{78}$ Id. Madison's actual words as reported in the Virginia ratification debates were:

Where a technical word was used [trial by jury], all the incidents belonging to it necessarily attended it. The right to challenge is incident to the trial by jury, and, therefore, as one is secured, so is the other.

Id.

79 If [the people] dare oppose the hands of tyrannical power, you will see what has happened elsewhere. They may be tried by the most partial powers, by their most implacable enemies, and be sentenced and put to death, with all the forms of a fair trial. . . . I would rather the trial by jury were struck out altogether. There is no right of challenging partial jurors.... Yet the right is as valuable as the trial by jury itself.

Id.

80 "In all criminal prosecutions, the accused shall enjoy the right to a speedy and public trial by an impartial jury of the State and district wherein the crime shall have been committed ...." US Const, Amend VI. There is arguably some ambiguity in the framers' Sixth Amendment debate over "challenges," owing to the then-colonial practice, and the current English practice, of sometimes referring to both peremptory challenges and challenges for cause with the single word "challenges." Judge Broderick appears to view this debate between Madison and Henry as encompassing the peremptory challenge. Broderick, 65 Temple L Rev at $374 \mathrm{nn} 28-29$ (cited in note 2). Nevertheless, it seems clear, at least from the context in which Professors Hans and Vidmar have reported this debate, that it was about the challenge for cause, and not about the peremptory challenge:

$\mathrm{A}[\mathrm{n}]$ issue of contention concerned the spelling out of the right to challenge jurors. As we already noted, English law did not allow challenges for general bias. The House of Representatives was, however, very specific on this right in its first draft of the Bill of Rights. ... The Senate eliminated this clause, largely on the grounds that it was redundant with the guarantee of an "impartial jury." 
By contrast, I am unaware of any recorded discussion by the framers of the peremptory challenge, or of any draft of any constitutional provision-original or amendment-referencing the peremptory challenge. The Constitution is and always has been utterly silent when it comes to the peremptory challenge. ${ }^{81}$

In 1919, the Supreme Court held in Stilson v United States that "[t]here is nothing in the Constitution of the United States which requires the Congress to grant peremptory challenges to defendants in criminal cases; trial by an impartial jury is all that is secured." 82

But Congress quite early on codified portions of the English practice regarding peremptory challenges. In 1790 , it directed that a federal criminal defendant would be given thirty-five peremptories in treason cases and twenty in all other capital cases. ${ }^{83}$ This statute did not address the question of a defendant's right to peremptory challenges in non-capital federal cases. Nor did it make any mention of the prosecution's peremptories, or of the English practice of standing aside, thus leaving the federal courts with the open question of whether the prosecution had any common law right to peremptory challenges in either form.

Before 1856, the general belief and practice seems to have been that the prosecution did have a right to some peremptory challenges, and perhaps even to an unlimited number via the practice of standing aside, presumably as a matter of federal common law. ${ }^{84}$ That idea was rejected by the Supreme Court in

[T]hese debates indicated that, unlike English practice, it was intended that in a pretrial hearing, or voir dire, as it was called, defendants should have the right to challenge and reject jurors for their general attitudes as well as specific interests in the case.

Hans and Vidmar, Judging the Jury at 37-38 (cited in note 77) (citation omitted).

${ }^{51}$ See US Const, Amend VI. The Seventh Amendment, which guarantees the right to a jury in most federal civil cases, similarly does not make any mention of the peremptory challenge. US Const, Amend VII.

250 US 583, 586 (1919).

1 Stat $119(1790)$.

s This position was taken by Justice Story, in dictum, in United States $v$ Marchant, 25 US (12 Wheat) 480, 483-84 (1827). Presumably in no small part due to Justice Story's prestige, this view was accepted by most federal judges until the Court revisited the issue in United States $v$ Shackleford, 59 US (18 How) 588 (1856). Van Dyke, Jury Selection Procedures at 149 (cited in note 51). But see United States v Douglass, 25 F Cas 896, 900 (C C NY 1851) (Betts dissenting):

The whole theory of criminal jurisprudence looks to placing the advantage, if one accompanies the cause, on the side of the accused; and I think that, after the efforts almost universally put forth in the United States to strengthen and extend such privilege, particularly to a person on trial for his life, we are taking a long step backwards in setting up the practice of the English assizes, originating in an era of colder sympathy for human life than prevails in our era and in the jurisprudence of 
1856 in United States $v$ Shackleford, which held that neither the prosecutor's peremptory challenge nor the right to direct jurors to stand aside was rooted in federal common law, and that federal courts should instead look to state procedures to decide whether to allow the prosecution peremptory challenges or standing aside. ${ }^{85}$

In 1865, in response to Shackleford, Congress specified that in all non-capital felony cases the defendant would have ten peremptory challenges and the prosecution two.$^{86}$ In this same statute Congress decreased the number of defense peremptories in capital cases from thirty-five to twenty, and granted the prosecution five. ${ }^{87}$ In 1872 , the number of prosecution challenges in nontreason, non-capital felony cases was increased from two to three. ${ }^{88}$ In the same statute, Congress for the first time extended the notion of peremptory challenges to federal civil cases (three for each side) and to federal misdemeanor cases (three for each side). ${ }^{89}$ In 1911, the numbers were again revised: twenty for the defendant and six for the prosecution in treason and other capital cases; ten for the defendant and six for the prosecution in other felony cases; three each in misdemeanor and civil cases. ${ }^{90}$ When the Federal Rules of Criminal Procedure were adopted in 1946, Rule 24(b) increased the prosecution's peremptories in capital cases to equal the defendant's at twenty. ${ }^{91}$ This is the current federal scheme.

the United States.

${ }^{85} 59$ US (18 How) 588, 590 (1856).

${ }^{36} 13$ Stat 500 (1865).

${ }^{87}$ Id.

ss 17 Stat 282 (1872).

$\Leftrightarrow$ Id.

${ }^{90} 36$ Stat 1166 (1911).

${ }^{91}$ Federal Rule of Criminal Procedure 24(b) provides:

If the offense charged is punishable by death, each side is entitled to 20 peremptory challenges. If the offense charged is punishable by imprisonment for more than one year, the government is entitled to 6 peremptory challenges and the defendant or defendants jointly to 10 peremptory challenges. If the offense charged is punishable by imprisonment for not more than one year or by fine or both, each side is entitled to 3 peremptory challenges. If there is more than one defendant, the court may allow the defendants additional peremptory challenges and permit them to be exercised separately or jointly.

Peremptory challenges in federal civil trials are established in 28 USC § 1870 (1994):

In civil cases, each party shall be entitled to three peremptory challenges. Several defendants or several plaintiffs may be considered as a single party for the purposes of making challenges, or the court may also allow additional peremptory challenges and permit them to be exercised separately or jointly. 
The evolution of the peremptory challenge in the various states has generally paralleled federal developments. By 1790, most states recognized by statute a defendant's right to some peremptory challenges, and most state courts shared the preShackleford federal view that the prosecution's right to some peremptories was grounded in the common law. ${ }^{92}$ By 1870-only fourteen years after the Court in Shackleford rejected the notion of a common law basis for a prosecutor's right to peremptory challenges-almost all the states had enacted statutory provisions granting the prosecution some peremptories. ${ }^{93}$ Today, every state recognizes some form of peremptory challenges for both sides in criminal and civil cases. ${ }^{94}$

\section{The Peremptory Challenge as the Last Best Tool of Jim Crow}

Like so many things in the United States, the marked difference between the American peremptory challenge and the English peremptory challenge can be traced to the agonies of slavery, civil war, and Reconstruction. While the English version of the peremptory challenge was withering from disuse, the American version was vigorously and comprehensively being applied in attempts to stem the inevitable tide of civil rights.

Until Reconstruction, the peremptory challenge does not appear to have been used extensively to exclude disfavored racial or ethnic groups, probably for the simple reason that, as in England, those groups were excluded quite effectively at the front end by restrictive laws on juror qualification..$^{95}$ In America, this

\footnotetext{
${ }^{22}$ See Swain v Alabama, 380 US 202, 215-17 \& nn 16-20 (1965). Of course, even after Stilson and Shackleford, state courts were free to hold that a prosecutor's right to peremptory challenges was guaranteed by the state constitution, though Ive found no such reported cases. See State $v$ Kelly, 362 S2d 1071, 1081-82 (La 1978) (Dennis concurring) (Louisiana Constitution has never recognized prosecutor's right to peremptory challenges).

${ }^{93}$ Swain, 380 US at $216 \mathrm{n}$ 18. Interestingly, the slave states were first to enact statutes giving the peremptory challenge to the prosecution, with Alabama and Georgia leading the way in 1820 and 1833, respectively. Douglas L. Colbert, Challenging the Challenge: Thirteenth Amendment as a Prohibition Against the Racial Use of Peremptory Challenges, 76 Cornell L Rev 1, 11 n 39 (1990). The first northern state to give the peremptory challenge to the prosecution was Rhode Island, in 1854. Id.

${ }^{4}$ Morehead, 43 DePaul L Rev at 628 \& $n 23$ (cited in note 2).

s As late as the eighteenth century, jury service in England was limited to male freeholders under seventy years of age, and even 75 percent of that elite group was insufficiently wealthy to qualify. Douglas Hay, The Class Composition of the Palladium of Liberty: Trial Jurors in the Eighteenth Century, Cockburn and Green, eds, Twelve Good Men at 305, 349, 357 (cited in note 54). In a sample of 181 defendants tried in Staffordshire in a single year in the 1700s, only 2 percent would themselves have qualified as jurors, and none of those charged with felonies or theft would have qualified. Id at 350-51.
} 
front-end exclusion was accomplished not only by slave codes in the South, and even express disenfranchisement of free blacks in the North, but also by a myriad of facially neutral barriers to juror qualification that were erected in both the South and North. ${ }^{96}$ Since juror qualification was initially tied to voter qualification, the de jure and de facto disenfranchisement of blacks served also to exclude them as jurors. ${ }^{97}$

Emancipation did not markedly change the situation. The boldest states simply reenacted the slave codes. ${ }^{98}$ Most states, by enacting the so-called Black Codes, either retained their express racial barriers or retained their power to exclude blacks and others with a variety of qualifications (for example, poll taxes, property ownership, educational background, residence). ${ }^{99}$ Just in case any undesirables managed to slip through these objective economic barriers, most states also erected a second line of defense consisting of wholly subjective "character" qualifications ("intelligence," "approved integrity," "good character"), to be determined by local officials in the course of putting together lists of prospective jurors. ${ }^{100}$ Finally, many states expressly or impliedly adopted the so-called "key man" method of summoning jurors, in which a designated county official-usually one who was politically well-connected-was charged with making all of the qualification decisions and putting together all of the jury lists. ${ }^{101}$

As the engine of Reconstruction began to drive the last vestiges of express racial barriers to jury service out of the state law codes, Congress passed the Civil Rights Act of 1875, which crimi-

\footnotetext{
${ }^{96}$ Slaves, of course, had no right to vote and no right to serve on juries. Even free blacks were expressly disenfranchised in Delaware in 1792, in Kentucky, Maryland and Ohio in 1799, and in New Jersey in 1807. Richard Kluger, Simple Justice: The History of Brown v. Board of Education and Black America's Struggle for Equality 32 (Vintage 1977). Even in states where slavery was not practiced but also not outlawed, free blacks were generally afforded voting rights, and therefore jury eligibility, see note 97 , only after meeting unrealistic and discriminatory qualifications. Id at 38. For example, black citizens in antebellum New York could vote, and therefore serve on a jury, only if they owned at least $\$ 250$ worth of property. No such requirement applied to whites. Id. See generally Paul Finkelman, Prelude to the Fourteenth Amendment: Black Legal Rights in the Antebellum North, 17 Rutgers L J 414 (1986) (arguing that pre-Civil War era expanded civil rights for blacks in the antebellum North).

${ }^{37}$ Colbert, 76 Cornell $L$ Rev at $31 \mathrm{n} 140$ (cited in note 93).

${ }^{93}$ See, for example, An Act to confer Civil Rights on Freedmen, 1865 Miss Laws $\S 4$ at $82,83-86$.

${ }^{9}$ See Colbert, 76 Cornell L Rev at 76 (cited in note 93); Theodore Brantner Wilson, The Black Codes of the South (Alabama 1965).

${ }^{100}$ Colbert, 76 Cornell L Rev at 75-77 (cited in note 93).

${ }^{101}$ Van Dyke, Jury Selection Procedures at 55 (cited in note 51). The "key man" method of summoning jurors was expressly outlawed by Congress in 1968. See text accompanying notes 127-29.
} 
nalized any de jure exclusion of jurors based on race. ${ }^{102}$ Still, many southern states boldly continued to enforce state statutes expressly excluding blacks from jury service. In Strauder $v$ West Virginia, the Supreme Court invalidated these de jure exclusions. ${ }^{103}$ However, on the same day it decided Strauder, the Court in Virginia $v$ Rives refused to strike down a state's de facto exclusion of blacks from juries, opining that state courts could adequately redress a claim of de facto racial exclusion. ${ }^{104}$

Despite the presence of comprehensive patent and latent exclusion mechanisms (not to mention widespread physical intimidation $^{105}$ ) some southern blacks trickled through the system and ended up as prospective jurors. Indeed, as early as 1870, integrated venires-that is, panels of prospective jurors with at least one black person in them-were not uncommon in several southern states. ${ }^{106}$ Prosecutors were then forced to turn to the peremptory challenge to eliminate the new black faces appearing for jury duty.

From Reconstruction through the civil rights movement, the peremptory challenge was an incredibly efficient final racial filter. When Mr. Swain, of Swain v Alabama ${ }^{107}$ fame, was convicted by his all-white Talladega County jury in the early 1960s, no black person had sat on any Talladega County trial jury, civil or criminal, in living memory. ${ }^{108}$ No black person sat on any criminal jury in Talladega County, trial jury or grand jury, for the thirteen years immediately preceding Swain..$^{109}$ In 1963 , the Alabama Supreme Court itself summed up with chilling simplicity the Jim Crow effectiveness of the peremptory challenge: "Negroes are commonly on trial venires but are always struck by attorneys in selecting the trial jury."110 The systematic exclusion of black jurors was not limited to the Deep South. For example, as late as 1880 , no black person had ever served as a juror in Delaware. ${ }^{111}$

${ }^{162} 18$ Stat, Pt 3 at 335 (1875).

${ }^{133} 100$ US (10 Otto) 303, 309-10 (1879).

${ }^{10} 100$ US (10 Otto) 313, 318-22 (1879). A third jury rights case was decided on the same day as Strauder and Rives. In Ex Parte Virginia, the Court affirmed the conviction of a state trial judge under those provisions of the Civil Rights Act of 1875, 18 Stat, Pt 3 at 335-36, which prohibited state officials from excluding jurors based on race. 100 US (10 Otto) $339,347-48$ (1879).

${ }^{13}$ See generally Colbert, 76 Cornell L Rev at 39-42 (cited in note 93).

${ }^{105}$ Id at 49-50.

${ }^{107} 380$ US 202 (1965). See text accompanying notes 120-31.

${ }^{163}$ Id at 231-32 (Goldberg dissenting).

${ }^{200}$ Id at 205 (majority opinion).

${ }^{110}$ Swain v State, 275 Ala 508, 156 S2d 368, 375 (1963), affd, 380 US 202 (1965).

${ }^{\prime \prime}$ Neal $v$ Delaware, 103 US (13 Otto) 370,397 (1880). It is difficult to say whether, through the first half of this century, blacks in the North were just as effectively excluded 
It was against this backdrop of comprehensive and unabashed racial exclusion that the Supreme Court began its attempts to defang the peremptory challenge as a tool of racial segregation.

\section{BATSON, ITS PREDECESSORS, AND ItS PROGENY: THE PEREMPTORY IS NO LONGER PEREMPTORY}

The Supreme Court has traveled a long road from a suggestion it made in an 1887 case that peremptory challenges serve the useful function of screening out "criminal classes" in "large cities [where] there is such a mixed population." "12 Today, the law forbids purposeful racial, ethnic, and gender discrimination in the exercise of peremptory challenges. ${ }^{113}$ The length of that road, the pace of the journey, and the uncertainties of where it will eventually lead all reflect a deeply ambivalent view of the importance of the peremptory challenge. They also reflect the extent to which the peremptory challenge once was, and now may again be, a tool to prevent impartial juries rather than to ensure them.

\section{A. The Road to Batson}

The first significant step in this journey was Neal $v$ Delaware, an 1880 decision in which the Court recognized for the first time that state juror qualification laws had constitutional limits, and could not be used to effect a total exclusion of black jurors over a substantial period of time. ${ }^{114}$ This standard, of course, was an exceedingly difficult one for a complaining defendant to meet: not only did it require a showing of total exclusion of minority jurors from venires, it required that a defendant demonstrate that the exclusion pervaded over a "substantial" period of time-that is, in prior venires in that jurisdiction. Thus, Neal had the paradoxical effect of invigorating the peremptory challenge as a tool of racial exclusion: many states that still had highly restrictive juror qualifications relaxed those qualifications to permit a token number of blacks into jury venires, and those blacks were then excluded by peremptory challenges. ${ }^{115}$

\footnotetext{
from jury service as their southern brethren. There is almost no information about the racial characteristics of northern juries during that period. Colbert, 76 Cornell $L$ Rev at $88-89$ \& $n 438$ (cited in note 93 ).

${ }^{112}$ Hayes $v$ Missouri, 120 US 68, 71 (1887).

${ }^{13}$ See text accompanying notes 132-41.

11، 103 US (13 Otto) 370, 397 (1880).

${ }^{115}$ Several states unabashedly adopted procedures of admitting a few token blacks in every trial venire and grand jury for the specific purpose of insulating themselves from Neal. See, for example, Cassell v Texas, 339 US 282, 286 (1950) (noting in dicta that jury
} 
Even in the face of Neal, some states, such as Alabama, refused to relent on their comprehensive de facto exclusion of black jurors, explaining their absence as the benign product of state officials' application of facially-neutral qualifications. In Norris $v$ Alabama, the Court held that such an explanation for the total absence of black jurors was not constitutionally adequate, ${ }^{116}$ and that the Court would make an independent inquiry into whether a particular state's jury qualifications amounted to purposeful discrimination under Neal..$^{117}$

This promise proved greatly exaggerated. Only a handful of Supreme Court decisions struck down any system of state jury qualifications under the stringent standards of Norris and Neal. ${ }^{118}$ States continued to enforce facially neutral de facto exclusions, and state court venires continued to be overwhelmingly white. ${ }^{119}$

By the time the Court decided Swain v Alabama ${ }^{120}$-the 1965 case in which the Supreme Court addressed for the first time the issue of juror discrimination in the context of the peremptory challenge-the peremptory challenge was well entrenched as the last line of defense against the increasing pressures for desegregation of the venire. The Swain Court held that the Equal Protection Clause prohibited state prosecutors from using their peremptory challenges in a racially discriminatory way. But in order to overcome the presumption that peremptory challenges were exercised legitimately, a defendant had to demonstrate that the prosecutor had "systematically" used peremptories to exclude black jurors. ${ }^{121}$ This required something more than the mere fact that all blacks had been excluded in the case at hand, but presumably something less than the "total" exclusion over a "substantial" period of time as required in Neal. ${ }^{122}$

commissioner customarily permitted only one black juror on each grand jury).

${ }^{116} 294$ US 587, 596-99 (1935).

${ }^{117}$ Id at 589-90:

The question is of the application of this established principle [of Neal $v$ Delaware] to the facts disclosed by the record. That the question is one of fact does not relieve us of the duty to determine whether in truth a federal right has been denied.

${ }^{11}$ Van Dyke, Jury Selection Procedures at 54-56 (cited in note 51).

${ }^{11}$ For example, although nearly half of the 80,000 people living in Bibbs County, Georgia in 1940 were black, only 44 of 2,493 (1.8 percent) of the people summoned for jury duty in that year were black. Watkins $v$ State, 199 Ga 81, 33 SE2d 325, 333 (1945).

380 US 202.

${ }^{121}$ Id at 227.

${ }^{2}$ Justice White's majority opinion starts out sounding a lot like Norris and Neal:

[W] hen the prosecutor in a county, in case after case, whatever the circumstances, whatever the crime and whoever the defendant or the victim may be, is responsible for the removal of Negroes who have been selected as qualified jurors by the jury 
In practice, the Swain standard proved every bit as daunting as the Neal standard. Indeed, the proof problems inherent in the Neal inquiry were magnified by Swain, since it can be substantially more difficult to gather evidence about, and make inferences from, a prosecutor's past practices in exercising peremptory challenges than to simply collect hard and cold racial data from county jury records. To no one's surprise, Swain had no more impact on eliminating the racially-motivated use of peremptory challenges than Neal had on eliminating raciallymotivated juror disqualifications. ${ }^{123}$

Swain endured an unprecedented barrage of academic and judicial criticism, almost all condemning its naive view of the subtleties of racial discrimination and the cleverness of its prosecutorial practitioners. ${ }^{124}$ Some lower federal courts and state courts even turned to the Sixth Amendment (or to state equivalents), holding that the fair cross-section requirement of the Sixth Amendment applied to the make-up of the jury, not just to the venire, and invalidating the racial effects of peremptory challenges on this ultimately rejected constitutional ground. ${ }^{125}$

commissioners and who have survived challenges for cause, with the result that no Negroes ever served on petit juries, the Fourteenth Amendment claim takes on added significance. ... If the State has not seen fit to leave a single Negro on any jury in a criminal case, the presumption protecting the prosecutor may well be overcome.

Id at 223-24 (citation omitted). But later he makes it clear that something less than total exclusion over all time need be proved: " $[T]$ he defendant must, to pose the issue, show the prosecutor's systematic use of peremptory challenges against Negroes over a period of time." Id at 227.

${ }^{23}$ Bray, Comment, 40 UCLA L Rev at 527-31 (cited in note 1) (noting that exercise of peremptory challenges resulted in impermissible discrimination even after Swain). See also Van Dyke, Jury Selection Procedures at 58-62 (cited in note 51) (noting that later Court opinions undercut force of Swain).

${ }^{24}$ See, for example, Swain, 380 US at 246 (Goldberg dissenting) (arguing that Swain condones discriminatory procedures); People $v$ Wheeler, $148 \mathrm{Cal}$ Rptr 890, 583 P2d 748, 766-68 (Cal 1978) (same); Gurney, Note, 21 Harv CR-CL L Rev at 240 (cited in note 2) (observing that Swain standard is "all but impossible to satisfy"); Van Dyke, Jury Selection Procedures at 57-58 (cited in note 51) (arguing that Swain is inconsistent with earlier and later Court decisions).

${ }^{125}$ See, for example, Booker $v$ Jabe, 775 F2d 762, 767-68 (6th Cir 1985); Roman $v$ Abrams, 822 F2d 214, 224-25 (2d Cir 1987); Wheeler, 583 P2d at 761-62 (Cal 1978); Riley $v$ State, 496 A2d 997, 1008 (Del 1985); State v Neil, 457 S2d 481, 486 (Fla 1984); Commonwealth $v$ Soares, 377 Mass 461, 387 NE2d 499, 510-16 (1979). But several courts declined to extend the fair cross-section requirement from the venire to the sitting jury. See, for example, State $v$ Stewart, 225 Kan 410, 591 P2d 166, $171-72$ (1979); State v Raymond, 446 A2d 743, 745 (RI 1982).

The Supreme Court eventually resolved this conflict post-Batson, at least as a federal matter, in favor of the view that the fair cross-section requirement of the Sixth Amendment is limited to the procedures by which the venire is drawn, and does not apply to the procedures by which the jury is then selected from that venire. Holland $v$ Illinois, 493 US $474,477-88$ (1990). 
Other state courts constructed less demanding versions of the Swain test that were grounded on state equal protection provisions. ${ }^{126}$

In response to Swain, Congress enacted the Jury Selection and Service Act of $1968,{ }^{127}$ which expressly forbade the "key man" method of selection of the venire, ${ }^{128}$ and required instead that each federal district court appoint a jury selection commissioner who would then devise a plan for the summoning of prospective jurors from voter lists and other sources expressly designed to maximize a fair cross-section. The statute also expressly prohibited the exclusion of federal jurors on account of race, color, religion, sex, national origin, or economic status. ${ }^{129}$

The Supreme Court's Advisory Committee on Criminal Rules even joined the fray, proposing in 1976 that Rule 24(b) be amended to reduce significantly the number of peremptory challenges for each side, on the ground that the large number of existing peremptory challenges were sometimes being misused "to make systematic exclusions of a class of persons." rule change was approved by the Court but never adopted by Congress. ${ }^{131}$

\section{B. Batson and the Problem of Pretext}

The Court finally acted in Batson $v$ Kentucky, ${ }_{132}$ abandoning the Swain requirement that there be broad historical evidence of racial discrimination in the exercise of peremptory challenges, and permitting a defendant to focus instead on the prosecutor's motivations in the case at hand. Batson held that a defendant could overcome the presumption that peremptory challenges were used legitimately by making a prima facie case that the challenges in the case at hand were race-motivated (Batson step one), after which the burden would then shift to the prosecutor to articulate a race-neutral reason for the challenges (Batson step

\footnotetext{
${ }^{123}$ See, for example, Wheeler, 583 P2d at 758-62; Soares, 387 NE2d at 510-16. But see Commonwealth $v$ Henderson, $497 \mathrm{~Pa} \mathrm{23,} 438$ A2d 951, 952-55 (1981) (rejecting the approach taken in Wheeler and Soares).

${ }^{127} 28$ USC $\$ \$ 1861-69$ (1988).

${ }^{123}$ See text accompanying note 101. See also Davis $v$ United States, 411 US 233, 235 (1973) (discussing eradication of "key man" system).

${ }^{12} 28$ USC \& 1862 (1994).

${ }^{10}$ Notes of Advisory Committee on March 1990 Proposed Amendment to Rules, Rule 24, reported in USCS Rules 14-31 at 339 (1991).

${ }^{131}$ Id. In March 1990, the Advisory Committee again proposed a substantial reduction in the number of federal peremptory challenges, and an equalization (at six) of the number for each side in non-capital felony cases. Id. No action on this proposal has been reported.

${ }^{152} 476$ US 79 (1986).
} 
two). ${ }^{133}$ If a race-neutral reason were proffered, then the final step would be for the trial court to determine whether the challenger had met his or her burden of proving that the peremptory challenges were in fact exercised because of racial prejudice (Batson step three). ${ }^{134}$

Despite another firestorm of criticism, beginning at one end of the ideological spectrum with Justice Marshall's famous concurrence expressing the view that peremptory challenges should be abolished altogether, ${ }^{135}$ and currently embodied at the other end of the ideological spectrum in Justice Scalia's dissents in Edmonson v Leesville Concrete Co $^{136}$ and J.E.B. v Alabama ${ }^{137}$ the

${ }^{133}$ [A] defendant may establish a prima facie case of purposeful discrimination in selection of the petit jury solely on evidence concerning the prosecutor's exercise of peremptory challenges at the defendant's trial. To establish such a case, the defendant first must show that he is a member of a cognizable racial group, and that the prosecutor has exercised peremptory challenges to remove from the venire members of the defendant's race. Second, the defendant is entitled to rely on the fact, as to which there can be no dispute, that peremptory challenges constitute a jury selection practice that permits "those to discriminate who are of a mind to discriminate." Finally, the defendant must show that these facts and any other relevant circumstances raise an inference that the prosecutor used that practice to exclude the veniremen from the petit jury on account of their race.

-..

Once the defendant makes a prima facie showing, the burden shifts to the State to come forward with a neutral explanation for challenging black jurors.

476 US at 96-97 (citations omitted).

${ }^{234}$ Once a race-neutral explanation is given, "[t]he trial court then will have the duty to determine if the defendant has established purposeful discrimination." Id at 98.

${ }^{135}$ The decision today will not end the racial discrimination that peremptories inject into the jury-selection process. That goal can be accomplished only by eliminating peremptory challenges entirely.

...

The inherent potential of peremptory challenges to distort the jury process by permitting the exclusion of jurors on racial grounds should ideally lead the Court to ban them entirely from the criminal justice system. Justice Goldberg, dissenting in Swain, emphasized that "[w]ere it necessary to make an absolute choice between the right of a defendant to have a jury chosen in conformity with the requirements of the Fourteenth Amendment and the right to challenge peremptorily, the Constitution compels a choice of the former." I believe that this case presents just such a choice, and $I$ would resolve that choice by eliminating peremptory challenges entirely in criminal cases.

476 US at 102-03, 107 (Marshall concurring) (citations omitted).

${ }^{135}$ [T]oday's decision means that both sides, in all civil jury cases, no matter what their race (and indeed, even if they are artificial entities such as corporations), may lodge racial-challenge objections and, after those objections have been considered and denied, appeal the denials-with the consequence, if they are successful, of having the judgments then overturned. Thus, yet another complexity is added to an increasingly Byzantine system of justice that devotes more and more of its energy to sideshows and less and less to the merits of the case.

500 US 614, 645 (1991) (Scalia dissenting).

${ }^{137}$ Women were categorically excluded from juries because of doubt that they were 
Batson rule has survived, and in some sense has flourished. It now applies regardless of the race of the defendant or the race of the challenged juror (Powers $v$ Ohio); ${ }^{138}$ it applies in civil cases as well as criminal cases ( $E$ dmonson); ${ }^{139}$ it applies to defense challenges as well as prosecution challenges (Georgia $v$ McCollum); ${ }^{140}$ and it applies to challenges discriminating by gender (J.E.B. $)_{.}^{141}$

Of all these extensions of the Batson doctrine, Powers and McCollum are probably the most significant. They shifted the focus from a defendant's right not to have prospective jurors excluded because of race, to the rights of the prospective jurors not to be so excluded. By explicitly recognizing that a prospective juror has a protectible interest in not being excused for unconstitutional reasons, the Court added another constitutional right to those already in tension with the nonconstitutional system of peremptory challenges. It also raised the specter of a generalized equal protection attack on the very existence of the peremptory challenge: If a prospective juror has a right not to be excluded for constitutionally impermissible reasons, does he or she not also have a right not to be excluded for reasons which, by definition, cannot be rationally articulated? It is an odd constitutional right indeed which cannot be taken away for certain reasons, but which can freely be taken away for a universe of other unstated and unstatable reasons. ${ }^{142}$ It is also an odd constitutional right

competent; women are stricken from juries by peremptory challenge because of doubt that they are well disposed to the striking party's case. There is discrimination and dishonor in the former, and not in the latter-which explains the 106-year interlude between our holding that exclusion from juries on the basis of race was unconstitutional, and our holding that peremptory challenges on the basis of race were unconstitutional.

511 US 127, 160 (1994) (Scalia dissenting) (citations omitted).

${ }^{23 *} 499$ US 400, 406-10, 415-16 (1991) (permitting a defendant to object to race-based exclusion of jurors in peremptory challenges regardless of whether or not defendant shares same race).

${ }^{139} 500$ US at 618-28.

${ }^{16} 505$ US 42, 48-55 (1992).

${ }^{141} 511$ US at 129.

${ }^{162}$ Many have argued that by recognizing a prospective juror's right not to be peremptorily excused for unconstitutional reasons, Powers and McCollum represent the first ineluctable steps toward the conclusion that peremptory challenges are unconstitutional. See, for example, Broderick, 65 Temple L Rev at 399-401, 420 (cited in note 2) (arguing that peremptory challenges are at odds with Equal Protection); Harris, Note, $32 \mathrm{Wm} \&$ Mary L Rev at 1034-39 (cited in note 2) (same). This Fourteenth Amendment argument was made even before Powers and McCollum. See, for example, Alschuler, $56 \mathrm{U} \mathrm{Chi} \mathrm{L}$ Rev at 169-70, 201-09 (cited in note 1) (same). See also Note, Due Process Limits on Prosecutorial Peremptory Challenges, 102 Harv L Rev 1013, 1024-33 (1989) (recognizing a due process test to detect prosecutorial abuse of peremptory challenges). But see Underwood, 92 Colum L Rev at 736-42 (cited in note 2) (evaluating due process right to trial by jury). 
that can be taken away without explanation by a lawyer, but not by a state legislature. ${ }^{143}$

The mutations to Batson are probably far from over. The Court has begun to address the looming and perhaps intractable problem of pretext, most recently holding in Purkett $v$ Elem that after a prima facie case of discrimination is made out, and the burden shifts to the challenger to show a race-neutral reason, that reason need only be race-neutral, not necessarily plausible. ${ }^{144}$ The prosecutor in Purkett peremptorily excused two black men from the panel, offering the following as the race-neutral reason: "I don't like the way they looked, with the way the hair is cut, both of them. And the mustaches and beards look suspicious to me."145 The Court held that the proffered reason was sufficiently race-neutral to satisfy step two of Batson, and that any consideration of the plausibility of that reason must await step three. ${ }^{146}$

Purkett arose in the context of a habeas corpus proceeding in which the Court may have felt compelled to give a special level of deference to the state trial court's findings. ${ }^{147}$ Moreover, the actual impact of the decision is likely to be modest: a facially raceneutral but totally implausible reason will get the challenger past the second Batson step, but likely not past the third. Nevertheless, Purkett illustrates the inherent problem of identifying exactly what constitutes a "facially race-neutral" explanation. As the dissent notes, at some point a sufficiently narrowed "raceneutral" explanation can, in fact, be a cover for race discrimina-

${ }^{143}$ Professor Alschuler has made this point forcefully:

Imagine a statute that generalized the principle underlying any specific use of a peremptory challenge to exclude a prospective juror who could not be disqualified for cause. This statute might disqualify from jury service both people who smile at defense attorneys and people who smile at prosecutors, or it might disqualify from a jury anyone with a child the same age as the defendant and anyone with a child the same age as the complaining witness. Although the line drawn by this statute might be less offensive than many of the lines that lawyers draw in exercising peremptory challenges, it probably could not survive constitutional scrutiny.... The peremptory challenge is no better and may often be worse.

Alschuler, $56 \mathrm{U}$ Chi L Rev at 204 (cited in note 1).

${ }^{14} 115$ S Ct 1769, 1771 (1995).

${ }^{145}$ Id at 1770 .

${ }^{166}$ Id at 1771.

${ }^{147}$ Justice Stevens's dissent notes another procedural nuance: the only "factual finding" that the state trial judge made was that the defendant failed to meet Batson step one; that is, he failed to make out a prima facie case of discrimination. There were no findings as to Batson step two (whether the prosecution offered a race-neutral reason) or step three (whether the defendant met his burden of proving the juror was excused because of his or her race, and not because of the race-neutral reason). Id at 1772 (Stevens dissenting). 
tion. ${ }^{148}$ How exactly is a trial judge to decide whether a prosecutor's exclusion of the only black men in a venire is or is not racebased, when the proffered neutral explanation is that they have facial hair, and they are the only ones in the entire venire with facial hair? What if the proffered reason is something more closely associated with race, such as having curly hair? By dispensing with any plausibility requirement at step two of the Batson inquiry, the Purkett Court may be making it marginally more difficult for trial courts at step three to separate out nonsensical reasons that are truly race-neutral from nonsensical reasons that may indeed be pretextual.

\section{Extending Batson: Other Suspect Classifications}

An even more serious threat to the continuing vitality of Batson may come from the question of whether it should be extended beyond race and sex to include religion and national origin-two classifications traditionally deemed "suspect" under the Equal Protection Clause.

To date, the question of expanding Batson to national origin does not seem to have arisen in ways separate from the question of race. ${ }^{149}$ Thus, Hispanics are treated as a race for Batson purposes, without distinguishing, for example, between MexicanAmericans and Argentinean-Americans. ${ }^{150}$ Although logic seems to compel the conclusion that Batson must apply to peremptory challenges based on national origin, it is equally clear that such an extension would unleash an unseemly and uncontrollable parade of horribles, which perhaps explains why most courts have chosen to hide the national origin issue in the more familiar

\footnotetext{
${ }^{164}$ Indeed, Justice Stevens suggests that an explanation such as "I don't like his beard" is not constitutionally different from the explanation "I don't like his looks," and that without more such an explanation might be pretextual as a matter of law. Id at 1774. See David A. Sutphen, Note, True Lies: The Role of Pretext Evidence under Batson v. Kentucky in the Wake of St. Mary's Honor Center v. Hicks, 94 Mich L Rev 488, 497-503 (1995) (explaining Batson's standard of proof for discrimination); Richard C. Reuben, Excuses, Excuses, 82 ABA J 20 (Feb 1996) (noting that Purkett makes proving racial or gender discrimination more difficult); Joan E. Imbriani, Note, Prosecutor's Explanation For Exercise of Peremptory Challenges Need Only Be Race-Neutral, Not Persuasive or Plausible, When Intentional Racial Discrimination is Alleged-Purkett v. Elem, 115 S Ct 1769 (1995) (per curiam), 6 Seton Hall Const L J 911 (1996) (same). See also the discussion of when language may in fact be a pretext for race or ethnic discrimination at notes 153-55 and accompanying text.

${ }^{\text {"M }}$ Chief Justice Rehnquist has observed, in a context other than peremptory challenges, that classifications based on national origin are "the first cousins of race." Trimble $v$ Gordon, 430 US 762, 777 (1977) (Rehnquist dissenting).

${ }^{15}$ For a fascinating discussion of the historical and cultural oversimplification inherent in the term "Hispanic," see Alen v State, 596 S2d 1083, 1091-96 (Fla Dist Ct App 1992) (Gersten specially concurring).
} 
wrappings of race or even ethnicity. As Professor Alschuler noted in a pre-Powers context:

[I]n light of the historic enmity between China and Japan and their lack of a common language, a Japanese-American defendant [arguably] could not challenge the discriminatory exclusion of prospective Chinese-American jurors. One cringes at the prospect of turning constitutional rights on the invidious, irrelevant inquiries that Batson seems to contemplate. ${ }^{151}$

Judges will not only need to be amateur anthropologists, ${ }^{152}$ but amateur historians and linguists as well.

Although the Court has to date avoided the issue of national origin, it has stepped onto the similarly slippery slope of language, which of course is often a component of both national origin and ethnicity. In Hernandez $v$ New York, a plurality of the Court held that when a defendant made out a prima facie case that the prosecution had excluded bilingual Hispanic prospective jurors, the fact that those bilingual jurors had expressed some hesitancy about relying only on in-court English translations and not on the underlying in-court Spanish testimony was an appropriately neutral explanation. ${ }^{153}$ The Court held that a raceneutral reason was not discriminatory simply because it arguably would have an ethnically disproportionate impact. ${ }^{154}$

This issue is a terribly difficult one, because language is often an important component of ethnicity and national origin. As the plurality itself recognized, to excuse prospective jurors because of their proficiency in their native tongue rather than because their English is inadequate, is troubling at best; at worst, it may be constitutionally indistinguishable from excluding them because of their ethnicity or national origin. ${ }^{155}$

\footnotetext{
${ }^{151}$ Alschuler, 56 U Chi L Rev at $192 \mathrm{n} 150$ (cited in note 1).

${ }^{152}$ See text accompanying notes 220-21.

${ }^{153} 500$ US 352, 356-70 (1991).

${ }^{154}$ Id at 359-70.

${ }^{155}$ Our decision today does not imply that exclusion of bilinguals from jury service is wise, or even that it is constitutional in all cases. It is a harsh paradox that one may become proficient enough in English to participate in trial, only to encounter disqualification because he knows a second language as well.

Id at 371 (citation omitted). One could argue that Hernandez does not in fact take us all the way down this troublesome road, because it is grounded on the specific and articulated reluctance of the bilingual jurors in that case to disregard the in-court Spanish. Professor Marder takes this limited view. Marder, 73 Tex L Rev at $1115 \mathrm{n} 308$ (cited in note 2). See also Sheri Lynn Johnson, The Language and Culture (Not to Say Race) of Peremptory Challenges, $35 \mathrm{Wm}$ \& Mary L Rev 21 (1993). See generally Cheryl A. O'Brien, Note, Hernandez v. New York: Did the Supreme Court Intend to Overrule Batson's Standard of “Racially Neutral"? 15 W New Eng L Rev 315 (1993).
} 
Most problematic of all, however, is the question of whether Batson should be extended to religion. Though not yet addressed by the Supreme Court, this issue has been the subject of considerable caselaw and even more commentary. ${ }^{156}$ Although there is probably no principled way to resist the extension of Batson to religion, state and federal courts have quite regularly been willing to do so. ${ }^{157}$ The problem, of course, is that a religious belief is just one of many personal beliefs people hold, and which they are permitted to hold and then to express under the First Amendment. If a particular religious belief triggers Batson protection, so perhaps does a particular philosophical or political belief..$^{158}$ May a prosecutor constitutionally excuse all socialists from a jury panel? May a public defender constitutionally excuse all neoNazis?

Professor Bader has taken these arguments to their logical extreme, arguing that Batson should generally be extended to

\footnotetext{
${ }^{15}$ See the cases cited in note 157. As for commentary, see generally, Melissa Roth Triedman, Comment, Extending Batson v. Kentucky to Religion-Based Peremptory Challenges, 4 S Cal Interdisciplinary L J 99 (1994); J. Suzanne Bell Chambers, Note, Applying the Break: Religion and the Peremptory Challenge, 70 Ind L J 569 (1995); Furst, Note, Religious Freedom Restoration Act, 30 Valp U L Rev 761 (cited in note 1); Benjamin Hoorn Barton, Note, Religion-Based Peremptory Challenges After Batson v. Kentucky and J.E.B. v. Alabama: An Equal Protection and First Amendment Analysis, 94 Mich L Rev 191 (1995); Mason, Note, $29 \mathrm{Ga} \mathrm{L} \mathrm{Rev} 493$ (cited in note 1).

${ }^{177}$ See, for example, United States $v$ Clemmons, 892 F2d 1153, 1158 n 6 (3d Cir 1989) (suggesting Batson does not prohibit the exercise of peremptory challenges on the basis of religion); State v Malone, 570 NE2d 584, 589-90 (Ml App Ct 1991) (holding that a prosecutor may peremptorily excuse jurors who express strong religious convictions); State $v$ Davis, 504 NW2d 767, 769-71 (Minn 1993) (holding Batson does not apply to religion). But see People v Fudge, 7 Cal 4th 1075, 31 Cal Rptr 2d 321, 332-33 (1994) (in bank) (exercise of peremptory challenges based on ethnic, racial, or religious or similar grounds violates Art I, § 16, of California Constitution); State v Gilmore, 103 NJ 508, 511 A2d 1150, 115761 (1986) (applying equal protection analysis to peremptory challenges on basis of race, sex, national origin, religion, or color under the New Jersey Constitution); Casarez v State, 913 SW2d 468, 475-79 (Tex Crim App 1994) (jurors may not be peremptorily excused because of their religion). See also Joseph $v$ State, $636 \mathrm{~S} 2 \mathrm{~d}$ 777, 779-81 (Fla Dist Ct App 1994) (treating Jews as an ethnic group entitled to Batson protection).

${ }^{15}$ I am not unaware that in the establishment and free exercise arenas the Court has been called upon to define "religion," and therefore to exclude nonreligious behaviors from the protection of those clauses. See, for example, Lemon $v$ Kurtzman, 403 US 602 (1971) (finding statutory grants of state aid to church-related schools to violate First and Fourteenth Amendments). But if one part of the First Amendment (the free exercise and establishment clauses) is interpreted as a limitation on the exercise of peremptory challenges, it is difficult to understand on what principled basis other parts of the First Amendment (the speech and association clauses) should also not be interpreted to limit peremptory challenges. See, for example, Casarez, 913 SW2d at 491 (Meyers dissenting):
}

The treatment of religious creed as an inappropriate basis for peremptory exclusion cannot rationally be distinguished from a similar treatment of persons on account of their Libertarian politics, their advocacy of communal living, or their membership in the Flat Earth Society. 
prohibit discrimination based on a juror's protected speech and associations. ${ }^{159}$ In her own example, she suggests that Batson should prohibit a defense lawyer from peremptorily challenging members of Mothers Against Drunk Driving, even assuming the defense lawyer could demonstrate that members of MADD have a greater-than-average tendency to convict. ${ }^{160}$ What if the case were a DUI case? Presumably, prosecutors would also be barred from peremptorily excusing members of Drunk Drivers R Us. But why stop at associational rights? Does not a juror have a First Amendment right to publish "The Evils of Drunk Driving" or "Drunk Driving-Not So Bad After All," and do not the authors of those expressions of protected speech have a right not to have their constitutionally-grounded right to serve on a jury denied to them because of their speech? But why stop there? Are not all of a prospective juror's responses in voir dire protected in some fashion by the First Amendment, so that nothing a juror says in voir dire, short of establishing a challenge for cause, could be used to "interfere" with that juror's right to sit on the jury?

The peremptory challenge has been remarkably resilient in the face of the many assaults on its "peremptoriness" inflicted by Batson and the cases after Batson, but even its hardy constitution could not survive if these views about how the First Amendment meshes with the jury trial become law. Once a prospective juror's general beliefs are declared out of bounds for peremptories, only the tiniest informational platforms will be left from which counsel will be able to take their insupportable and illogical leaps into folk wisdom. Extending Batson to religion and then to protected speech and association would surely be the long-predicted death knell of the peremptory challenge. ${ }^{161}$

\footnotetext{
${ }^{159}$ Bader, 24 Hofstra L Rev at 567, 593-618 (cited in note 2) (discussing rationale behind expanding Batson).

${ }^{160}$ Id at 600 .

${ }^{181}$ Beyond the question of whether Batson applies to all traditionally suspect classifications, lies the treacherous question of whether it applies to the myriad of quasi-suspect classifications created by some of the Court's fluid equal protection cases, and perhaps also suggested by protective legislation. Of course, the Court has already entered these waters in J.E.B., by extending Batson to the quasi-suspect classification of gender. But what about other recognized or arguably quasi-suspect classifications, like illegitimacy, sexual preference, age, or physical disability? The answers are far from clear. Tve found no cases discussing Batson in the context of legitimacy or sexual preference. The few courts that have addressed the question of age have held that age is not an impermissible basis upon which to exercise peremptory challenges. See, for example, United States $v$ Cresta, 825 F2d 538, 544-45 (1st Cir 1987). Although there are no reported decisions extending Batson to prospective jurors with disabilities, at least one commentator has argued for such an extension. See generally, Mary A. Lynch, The Application Of Equal Protection To Prospective Jurors With Disabilities: Will Batson Cover Disability-Based Strikes?, 57 Albany L Rev 289 (1993). Of course, once Batson let the group genie out of
} 


\section{Peremptory Challenges and "Harmless Error"}

Finally, and quite apart from the relentless stretching of the Batson doctrine described above, there is yet another stark symptom of the mixed institutional feelings we have about peremptory challenges: a trial court's erroneous impairment of a party's exercise of peremptory challenges can in some circumstances be harmless.

This issue normally arises when a trial court erroneously denies a party's challenge for cause to a prospective juror, thus forcing that party to use up one of its peremptory challenges on that prospective juror. In Ross $v$ Oklahoma, a state trial court erroneously denied a capital defendant's challenge for cause to a juror made during the process of "death qualifying" the jury. ${ }^{162}$

the bottle, there really is no logical end to the groups-real and imagined-that will line up for its "protections."

Even if Batson is confined ultimately to race, ethnicity, and sex, the lower courts remain in turmoil over the precise way in which it applies to those kinds of group distinctions. The fundamental disagreement appears to be whether Batson forbids any discrimination based on those immutable characteristics, or only non-benign discrimination. One might have thought that after Powers and McCollum the answer to this question is obvious, and that all such discrimination is forbidden. See text accompanying notes 138-43. But applying Batson to ethnic discrimination, as opposed to racial discrimination, remains an analytical problem for many lower courts. Several have held that ethnic groups that may not be considered traditionally "disadvantaged" are not Batson-cognizable. See, for example, Murchu $v$ United States, 926 F2d 50, 54-55 (1st Cir 1991) (Irish-Americans not covered by Batson); United States v Bucci, 839 F2d 825, 832-34 (1st Cir 1988) (ItalianAmericans not covered by Batson without historical showing of discrimination); United States v Di Pasquale, 864 F2d 271, 275-77 (3d Cir 1988) (same). But see United States v Biaggi, 673 F Supp 96, 99-103 (E D NY 1987) (holding that Italian-Americans are covered by Batson). So now add political science and ethnic studies to the disciplines that trial judges must master in order to be able to rule on Batson challenges. See text accompanying notes $148-52$ and $220-21$.

${ }_{102} 487$ US 81 (1988). To "death qualify" a jury means, in its broadest sense, to ask prospective jurors during voir dire about their views on the death penalty, and, more specifically, to assure that those views will not interfere with a juror's ability to be fair and impartial. Thus, a prospective juror who expresses such strong opposition to the death penalty that he or she would automatically vote for an acquittal or for non-imposition of death may be challenged for cause, but mere opposition unconnected to an inability to apply the law to the facts is insufficient. Lockhart $v$ McCree, 476 US 162 (1986); Wainwright $v$ Witt, 469 US 412 (1985); Witherspoon v Illinois, 391 US 510 (1968). Similarly, a prospective juror with strong pro-death penalty views may not be challenged for cause simply because of those views, unless he or she would automatically vote to convict or to impose death regardless of the law and the facts. Morgan $v$ Illinois, 504 US 719 (1992). For a good discussion of the problem of death qualifying jurors, see James M. Carr, Note, At Witt's End: The Continuing Quandary of Jury Selection in Capital Cases, 39 Stan L Rev 427 (1987).

In Ross, the juror in question indicated during voir dire that he would automatically vote for the death penalty if the defendant were found guilty. Based on that response, the trial court erred when it denied the defendant's challenge of that juror for cause. Witherspoon, 391 US at 522-23.

For a particularly thought-provoking discussion of the way in which post-Batson per- 
Under Oklahoma law, as is the case in many states, ${ }^{163}$ when a party's challenge for cause is denied, that party must exercise a peremptory challenge as to that juror (if any peremptory challenges are left) in order to preserve the cause issue for appeal, and Mr. Ross's counsel did so. The Supreme Court nevertheless affirmed Mr. Ross's conviction, concluding that the trial court's error: (1) did not impair Mr. Ross's right to an impartial jury (which is certainly correct because there was no evidence or argument that the any of the jurors who actually heard the case were partial); ${ }^{164}$ and, much more mysteriously, (2) that the effective reduction in the number of peremptory challenges available to Mr. Ross did not rise to the level of a denial of due process. ${ }^{165}$ This second conclusion is mysterious in several different respects.

First, its rationale seems fundamentally tautological: the Court expressly relied on the fact that Oklahoma law required Mr. Ross to use one of his peremptories on the unexcused juror, and from that fact it concluded that Mr. Ross received "all [the peremptory challenges] that Oklahoma law allowed him . . ."166 Completing the syllogism, the Court then reasoned that since all that happened to Mr. Ross is that the state in effect reduced the number of his peremptory challenges, and since peremptory challenges are creatures of statute that could constitutionally be eliminated entirely, Mr. Ross suffered no injury of due process magnitude. ${ }^{167}$ But of course just because a state may constitutionally eliminate peremptory challenges entirely does not mean it may dole them out in a manner which itself violates due process. If Oklahoma law provided that defendants had nine peremptory challenges on even days but only eight on odd days (or that

emptory challenges mesh or don't mesh with the principles enunciated in Witherspoon, see Brown $v$ Rice, 693 F Supp 381, 389-94 (W D NC 1988), affd in part and revd in part, Brown v Dixon, 891 F2d 490 (4th Cir 1989) (reversing district courts holding that prosecutor violated Constitution by using peremptories on jurors who had reservations about the death penalty), also discussed in Alschuler, $56 \mathrm{U}$ Chi L Rev at 204-06 (cited in note 1).

${ }^{30}$ See note 204 and accompanying text.

${ }^{16 s} 487$ US at 86:

Any claim that the jury was not impartial, therefore, must focus not on [the juror whom defendant was forced to excuse peremptorily], but on the jurors who ultimately sat. None of those 12 jurors, however, was challenged for cause by [defendant], and he has never suggested that any of the 12 was not impartial.

${ }^{165}$ Id at 88-91.

${ }^{165}$ Id at 91.

${ }^{10}$ Because peremptory challenges are a creature of statute and are not required by the Constitution, it is for the State to determine the number of peremptory challenges allowed and to define their purpose and the manner of their exercise.

487 US at 89 (citations omitted). 
black defendants got nine and white defendants only eight), the Ross majority might say that a defendant unfortunate enough to be tried on an odd day (or to be white) got "all the peremptory challenges allowed him by law." Of course that explanation does nothing to address the underlying constitutional issue, which is whether the manner in which these nonconstitutional rights were distributed was itself constitutional.

It is true that Mr. Ross received all the peremptories he was allowed, but he was erroneously forced to use one of those on a juror who should have been excused for cause. Of what possible due process significance is the fact that Oklahoma is one of many jurisdictions that requires a peremptory challenge to be used against a juror before a party may argue on appeal that the trial court erred in denying a challenge for cause to that juror? Whether a defendant, like Mr. Ross, is forced to use up one of his peremptory challenges to preserve his cause argument on appeal, or whether he is forced, in the absence of such a procedural requirement, to use up one of his peremptory challenges to ensure that the biased juror is not seated, is quite beside the point. In either case, he must use up one of his peremptory challenges to excuse a juror who should have been excused for cause.

The second mysterious thing about Ross is that it seems contrary to the Court's holding in a 1987 case, Gray $v$ Mississippi ${ }^{168}$ which established a rule of per se reversal when a trial court errs in granting a prosecution challenge for cause related to deathqualifying the jury, even though the prosecution arguably had unexercised peremptory challenges and could have used them on the juror had the trial court denied the challenge for cause. ${ }^{169}$ As

${ }^{163} 481$ US 648 (1987).

${ }^{169}$ Id at 659 . The trial court in Gray got just about everything wrong in ruling on challenges for cause. The prosecution was forced to exercise five or six of its twelve peremptory challenges to exclude jurors who expressed hesitation about the death penalty in such a way that they should probably have been excused for cause. Id at 652-55. See the discussion of Witherspoon at note 162. After the state had exhausted all of its peremptory challenges, a replacement prospective juror stated that although she was opposed to the death penalty, she could impose it in an appropriate case. Gray, 481 US at 653. Under Witherspoon and its progeny, that juror should not have been excused for cause, yet the trial court excused her for cause. Perhaps sensing that it had earlier erred when it forced the prosecution to use up many of its peremptories on jurors who should have been excused for cause, the trial court hinted that additional prosecutorial peremptories might be in order, but never awarded any, because instead it erroneously excused the juror for cause. Gray, 481 US at 654-55. Of course, the juror who eventually replaced that juror voted, along with all the other seated jurors, for conviction and for the death penalty. Id at 656. The Supreme Court held that the trial court's error in removing the juror for cause was not harmless, and indeed required per se reversal. Id at 667-68. See also Davis $v$ Georgia, 429 US 122, 123 (1976) (Witherspoon error not harmless just because other anti-death penalty jurors were not excluded). For a discussion of Batson harmless error, 
the dissent in Ross points out, the majority's attempt to distinguish Gray amounts to nothing more than an unarticulated unwillingness to "extend" Gray beyond its narrow facts. ${ }^{170}$ It is hard to understand how the error in Gray triggered per se reversal, despite the fact that that error could have been wiped clean by a prosecution peremptory, while the peremptory challenge which Mr. Ross was erroneously forced to exercise was deemed harmless. If anything, Ross involved a substantially more direct intrusion into a defendant's exercise of peremptory challenges than did Gray.

Finally, it may be very difficult for the Ross majority to limit its holding to the facts in that case, particularly now that Powers v Ohio ${ }^{171}$ and Georgia $v \mathrm{McCollum}^{172}$ have shifted the constitutional focus from litigants' rights to prospective jurors' rights. How can an erroneous Batson ruling ever be anything but harmless if we are indeed talking about the rights of prospective jurors and not about the rights of litigants?

In any event, the very fact that Ross recognizes that in some circumstances a trial court's erroneous interference in a party's exercise of peremptory challenges may be harmless, speaks volumes about the ambivalence the Court continues to feel about the role of the peremptory challenge.

\section{NOT ONLY IS THE CURE OF THE PEREMPTORY CHALLENGE WORSE THAN THE DISEASE, IT IS THE DISEASE}

Many critics of the peremptory challenge have described it as a tool whose original purposes were legitimate, but which over

and its relationship to the idea that a party must "preserve" arguments that a challenge for cause should have been granted by striking that juror peremptorily, see note 204 .

${ }^{170} \mathrm{I}$ believe that [the majority's] conclusion is irreconcilable with this Court's holding just last Term that a similar Sixth Amendment error in capital jury selection requires resentencing if "the composition of the jury panel as a whole could possibly have been affected by the trial court's error.". . . The Court's attempt to distinguish Gray not only fails to persuade, but also fails to protect petitioner's Sixth Amendment right to an impartial jury by condoning a scheme that penalizes the assertion of that right. I am convinced that application of Gray's per se resentencing rule in this case is the only course consistent with the Sixth Amendment. ...

The Court today unaccountably refuses to apply [the Gray] per se rule in a case involving a similar Sixth Amendment error. Here the trial court, rather than excusing a qualified juror, refused to excuse a biased juror. The defense's attempt to correct the court's error and preserve its Sixth Amendment claim deprived it of a peremptory challenge. . . . Even the Court acknowledges that the defense's loss of a peremptory challenge meets the Gray test.

487 US at 92-93 (Marshall dissenting) (citations omitted).

${ }^{171} 499$ US 400 (1991). See text accompanying notes 138, 142-43.

${ }^{172} 505$ US 42 (1992). See text accompanying notes 140, 141-43. 
time has either outlived its usefulness or has been used for illegitimate purposes. ${ }^{173}$ These critics praise by faint condemnation. Although the American strain of the peremptory challenge-with its racist traditions s $^{174}$ and post-Batson Orwellianism ${ }^{175}$-may well have been turned away from its original English purposes, it doesn't necessarily follow that those original purposes were automatically legitimate by virtue of tradition and history. Indeed, a case can be made that the peremptory challenge has never had any legitimate purpose.

The historical distinction we must keep in mind is between prosecutorial peremptories and defense peremptories. The first English peremptories were the Crown's unlimited peremptories in capital cases; the defendant's thirty-five peremptories were merely granted to counter the Crown's power. ${ }^{176}$ What disease were the Crown's unlimited number of peremptory challenges originally designed to cure?

The royal answer in England was not-as it was in the American South five centuries later-that the peremptory challenge was to serve as a second line of defense to the democratization of the venire. ${ }^{177}$ Rather, the purpose of the peremptory challenge was more basic: to eliminate jurors for cause. In reality, the Crown's unlimited number of peremptory challenges began as challenges for cause coupled with the principle of royal infallibility. If the King's prosecutors asserted that a prospective juror should not sit, then that juror was presumed to have some connection with the case sufficient to require his removal for cause, and no further inquiry was needed. ${ }^{178}$

\footnotetext{
${ }^{173}$ See, for example, Gurney, Note, 21 Harv CR-CL L Rev at 244-56 (cited in note 2) (arguing for abolition of peremptory challenges); Melilli, 71 Notre Dame L Rev at 502 (cited in note 2) (concluding that Batson has outlived its usefulness); Morehead, 43 DePaul L Rev at 632-36 (cited in note 2); Pizzi, $1987 \mathrm{~S} \mathrm{Ct} \mathrm{Rev} \mathrm{at} \mathrm{123-44} \mathrm{(cited} \mathrm{in} \mathrm{note} \mathrm{2)}$ (critiquing Batson).

${ }^{17}$ See text accompanying notes $95-111$.

${ }^{175}$ See text accompanying notes $142-72$, and notes $221-23$.

${ }^{10}$ See text accompanying notes $47-50$.

${ }^{17}$ Indeed, although the early English venire was by no means comparable in its diversity to the modern American version, see note 95, as early as the eighteenth century it was "a reasonably democratic institution," at least by standards of that time. Alschuler, $56 \mathrm{U}$ Chi L Rev at $165 \mathrm{n} 49$ (cited in note 1). It excluded all women, all men over seventy, peers and certain occupations, including some doctors, soldiers and clerics. Id. Yet it was easier to qualify to sit on an eighteenth-century English jury than it was to qualify for the House of Commons or even to hunt game. Id.

${ }^{17}$ Van Dyke, Jury Selection Procedures at 148 (cited in note 51): "[T] he English judges have assumed that cause existed whenever the Crown wants to challenge a juror." The King's prosecutors reportedly exercised their so-called "peremptory" challenges by stating "quod non boni sunt pro rege," or "because they are not good for the King." Proffatt, Trial by Jury $\$ 159$ (cited in note 14).
} 
Thus, the royal peremptory challenge was not really a peremptory challenge at all, and it did not really become peremptory until it was given in its non-royal form to defendants. ${ }^{179}$ This of course also explains the otherwise inexplicable fact that the Crown had an unlimited number of peremptory challenges. Actually, both the Crown and the defendant had an unlimited number of challenges for cause; the Crown simply had no obligation to articulate the cause.

By 1305, when all facets of royal infallibility were coming under attack, Parliament attempted to no avail to eradicate entirely the notion that the King's prosecutors were infallible in their detection of disqualified jurors. ${ }^{180}$ Parliament's choice of language is instructive:

That from henceforth, notwithstanding it be alleged by them that sue for the King, that the Jurors of those Inquests, or some of them, be not indifferent for the King, yet such Inquests shall not remain untaken; but if they that sue for the King will challenge any of those jurors, they shall assign of their Challenge a Cause Certain and the truth of the same Challenge shall be enquired of according to the custom of the court.... ${ }^{181}$

This language gives further credence to the idea that the cause was always present, but simply undisclosed. It corroborates the idea that the King's unlimited peremptories were actually unarticulated challenges for cause.

When Parliament failed in its efforts to kill this remnant of royal infallibility, the defective gene was inherited by defendants, and then passed on to American prosecutors and defense lawyers. There is no small amount of irony in the fact that modern lawyers' deeply held belief in their ability to ferret out hidden juror bias may well have as its historical and structural antecedent the now decidedly out-of-fashion notion that the King can do no wrong.

The fact that the peremptory challenge sprang to life as a corollary to the axiom of royal infallibility is terribly important, not only to understand why it was abolished in England and why its abolition in America is long overdue, but also to understand those nagging institutional doubts about peremptory challenges with which we as judges, jurors, lawyers, litigants, and citizens seem to have struggled for the last five hundred years. The ideas

\footnotetext{
${ }^{179}$ See text accompanying notes 47-50.

${ }^{180}$ See text accompanying note 59.

${ }^{181} 33 \mathrm{Edw} 1$ (1305) (Eng) (emphasis added).
} 
that the peremptory challenge is decidedly undemocratic, that it is susceptible to significant abuse by authorities, and that it is inherently irrational, all flow directly from the fact that the peremptory challenge is actually the lost heir of the divine right of kings. Something is fundamentally wrong with a jury selection system in which a lawyer can excuse perfectly qualified and objectively impartial jurors without offering any explanation. The something that is fundamentally wrong is that lawyers are no more infallible than kings.

Even ignoring its origins in the doctrine of royal infallibility, there is a second fundamental way in which the peremptory challenge is historically incongruous with our modern notions of the jury: peremptory challenges were invented two hundred years before the idea of impartiality ever applied to jurors. English jurors in the middle of the thirteenth century, when peremptory challenges first appeared, were still witnesses, selected precisely for their lack of independence. ${ }^{182}$ It would be another two hundred years before their role as impartial fact-finders would be fully crystallized. ${ }^{183}$ By that time, the English peremptory challenge was already an old remnant of the struggle between King and Parliament, and that struggle had nothing to do with juror impartiality.

Indeed, once jurors stopped being witnesses, and impartiality became the pole star of the English jury, the struggle between King and Parliament began to lose meaning in the context of the jury: jurors now served the role of impartial, independent factfinders, rather than witness-proxies for King or lord. It is hardly surprising, given this history, that the round hole of the peremptory challenge has never quite fit into the square peg of juror impartiality.

When we cogitate today about what exactly the peremptory challenge has to do with jury impartiality, we should not be ashamed to say "nothing." That was true for at least two hundred years, and I suspect it has always been true. Jury impartiality is grounded on two complementary institutional commitments: the commitment to include broad segments of the population as prospective jurors, and the commitment to exclude from those broad segments individual jurors who simply cannot be fair in a particular case. The peremptory challenge has nothing whatever to do with the commitment to a broad cross-section, and in fact it

\footnotetext{
${ }^{152}$ See text accompanying notes 22-25.

${ }^{1 \approx}$ See note 25 and accompanying text.
} 
threatens to render that commitment hollow. ${ }^{184}$ Nor does it have much to do with the task of rationally and honestly separating partial jurors from impartial jurors. ${ }^{185}$ It is a true historical remnant; not only a quaint vestigial tail on the royal prerogative, but perhaps also a dangerous appendix waiting to burst in the gut of the Sixth Amendment.

\section{THE EXTRAORDINARY CONDITIONS THAT GAVE RISE TO THE PEREMPTORY CHALLENGE, AND SUPPORTED ITS CONTINUATION, DO NOT EXIST TODAY}

If anything is clear about the history of the English peremptory challenge, it is that a criminal defendant's right to peremptory challenges was a relatively moderate response to two extraordinary and, from Parliament's point of view, intolerable conditions: the Crown handpicked all prospective jurors, and the Crown theoretically exercised an unlimited number of peremptory challenges. Given these two conditions, thirty-five defense peremptories seemed a measured response to the Crown's loaded deck. Even after Parliament abolished all prosecutorial peremptories in 1305, the Crown retained its power to select prospective jurors, and this power in and of itself likely justified continuation of the defendant's common law right to thirty-five peremptories. It probably came as no surprise to the more cynical members of Parliament that before the ink was dry on its abolition of all prosecutorial peremptories, the King's courts entirely circumvented that abolition by adopting the procedure of standing aside.

It is also no surprise that as the English jury became more and more diverse, and the Crown's role in handpicking jurors became less and less direct, the need for peremptories declined. It appears that the peremptory challenge withered and eventually died in England for the same reason most institutions do: it simply no longer served any function. In the beginning, it may have been an important tool for the protection of the individual defendant against the excesses of the Crown. But as Parliament steadily reduced the power of the Crown, so too was the potential for jury abuse reduced. As the qualifications for English jury duty became more and more open, there simply was no need, and no temptation, for any protections above and beyond the challenge for cause. ${ }^{186}$

\footnotetext{
${ }^{134}$ See text accompanying notes 230-35.

${ }^{185}$ See text accompanying notes 212-29.

${ }^{185} \mathrm{It}$ is curious how increased diversification of the venire was seen by the English as
} 
The American experience was quite different. The barriers to jury service in the United States were not gradually and peacefully lowered over a period of centuries; they were torn down rapidly in the violence of civil war. Southern states resisted at every turn, and when faced with the inevitability of desegregated venires, they turned to the peremptory challenge as the primary tool to keep blacks off juries.

In very much the same way that the peremptory challenge in England was used by Parliament as a device to restrict the power of the King, the peremptory challenge in the United States was used by states to restrict the desegregating power of the federal government. So one way to look at the differences between the English experience and the American experience is to consider America's civil rights struggle as effecting a kind of remission in the natural degeneration of the peremptory challenge.

To be sure, the peremptory challenge enjoyed a more favorable place in the history of the United States, even apart from the states' resistance to civil rights. All indications are that throughout our history, even in colonial times, and in the North as well as the South, whenever peremptory challenges were available American lawyers exercised them, and did so in numbers and frequency far exceeding the English custom. It is not entirely clear why the American strain of the peremptory challenge has been so robust, especially in the face of the now discredited racial history in which it played so significant a part. The most cynical among us might say that the peremptory challenge today serves precisely the same racist and sexist functions it has served throughout our history, and that it is being used the same old way it has always been used, save for some nominal and meaningless extra hoops now required by Batson. Indeed, there is some evidence to support this suggestion. ${ }^{187}$ The most naive among us might suggest that Batson has eradicated the racist and sexist aspects of the peremptory challenge, and that peremptory challenges now effectively serve the function they were designed to serve before they were hijacked by the forces of

a reason to dispense with peremptory challenges, while in America even the constitutionally grounded command of a fair cross-section has not driven the peremptory challenge away.

${ }^{157}$ It appears that prosecutors in southern and border states continue to use peremptory challenges at a rate significantly higher than most of their northern colleagues. See note 192. There is also evidence to suggest that the peremptory challenge is used at a high rate in some northern cities with large black populations. See, for example, People $v$ Frazier, 127 Ill App 3d 151, 469 NE2d 594, 598-99 (1984), which, though pre-Batson, summarizes the shameful extent to which Chicago-area prosecutors used peremptory challenges to exclude minorities from juries. 
American segregation, though this explanation does not account for their withering away in England.

This American love affair with the peremptory challenge probably has many non-civil rights explanations: our founders' generalized distrust of governmental power, perhaps best represented by our federal system, in which the states themselves are a structural expression of that distrust; an overestimation of the historical significance of the English peremptory challenge; a freer and potentially more infecting press; ${ }^{188}$ a legal tradition more permissive of lawyers' excesses; and a more wooden adherence to principles of adversariness. ${ }^{189}$ All of these conditions probably played some role in forming a cultural agar in which the American peremptory challenge was able to flourish.

But there can be no doubt that the single most significant factor in extending the life of the peremptory challenge in the United States was its use as a tool to perpetuate the racial purity of juries. Now that that battle has been lost by the states, it is time to retire the peremptory challenge.

Today, constitutional and statutory guarantees are firmly in place, insuring not only open-ended, virtually unrestricted, juror qualification, ${ }^{190}$ but also race-neutral summoning mechanisms producing venires representing reasonably fair cross-sections of

\footnotetext{
${ }^{128}$ Because English courts have traditionally exercised more control over the press than American courts, some commentators believe the peremptory challenge in America assumed a more significant role in eliminating jurors whose hidden biases were the result of pretrial publicity. See, for example, Bray, Comment, 40 UCLA L Rev at $522 \mathrm{n} 22$ (cited in note 1), citing Pendleton Howard, Criminal Justice in England: A Study in Law Administration 362-64 (MacMillan 1931).

${ }^{189}$ See text accompanying notes 223-40.

${ }^{130}$ Under the Federal Jury Selection Act of 1968, the only statutory disqualifications from federal jury service are if the prospective juror:

(1) is not a citizen of the United States eighteen years old who has resided for a period of one year within the judicial district;

(2) is unable to read, write, and understand the English language with a degree of proficiency sufficient to fill out satisfactorily the juror qualification form;

(3) is unable to speak the English language;

(4) is incapable, by reason of mental or physical infirmity, to render satisfactory jury service; or

(5) has a charge pending against him for the commission of, or has been convicted in a State or Federal court of record of, a crime punishable by imprisonment for more than one year and his civil rights have not been restored.

28 USC $\S 1865$ (1994). Most states have equally modest statutory requirements for jury service. See, for example, the Uniform Jury Selection and Service Act \& 8, in 13 Uniform Laws Annotated 453 (1986) (adopted entirely or substantially in Colorado, Hawaii, İdaho, Indiana, Maine, Minnesota, Mississippi and North Dakota). Id at 437.
} 
communities. ${ }^{191} \mathrm{I}$ am not so naive to suggest that racism, sexism, classism, ageism, homophobia, or a host of other human prejudices have been, or can ever be, eradicated from the jury selection procedure-either in assembling the venires or in selecting trial jurors from those venires-any more than they can be eradicated from the human condition. ${ }^{192}$ However, the institutional structures that permitted (and indeed encouraged) race, ethnic, and sex discrimination in the selection of venires and juries have been dismantled. Conditions today are so markedly different than they were in England in 1305, or even in Alabama in 1965, that both the most ponderously inert and the most deeply cynical among us must ask whether the peremptory challenge has any continuing utility, if it ever had any, as a mechanism to insure the impartiality of juries.

Even if one clings, as do some public defenders with whom I have discussed this question, to the notion that American venires

\footnotetext{
${ }^{151}$ Under the Federal Jury Selection Act of 1968, federal venires are drawn either from voter registration lists or lists of actual voters, at the option of each district or division. 28 USC $\S 1863(b)(2)$ (1994). In addition, each district must supplement those lists with other sources "where necessary to foster the policy and protect the rights secured" by the Act. Id. Most states have similar juror-summoning mechanisms. See, for example, the Uniform Jury Selection and Service Act \$ 5, in 13 Uniform Laws Annotated 445 (1986), which gives local jury commissioners the same option of voter registration lists or actual voter lists, and which also contains a laundry list of suggested additional sources: utility customers, tax rolls, motor vehicle registrations, and driver's license lists. Even these broad federal and state juror sources arguably underrepresent some groups of prospective jurors, including some racial and ethnic minorities, and perhaps also young people of all races and ethnic groups. See note 192. Nevertheless, I suspect that the gates of today's venire are as wide open as they have ever been in the history of the jury trial.

${ }^{152}$ My own experience as a trial judge in a large western city is that the people summoned for jury duty are reasonably reflective of the general population, with perhaps only some marginal underrepresentation of blacks, Hispanics and young people owing to the nature of our sources for jury lists (voter registration supplemented by motor vehicle registration). Yet it is also my sense, unsupported by any kind of formal or informal study, that the venires we actually see in court are more than marginally underrepresentative of blacks, Hispanies, young people, and men. We have a shockingly high 50 to 60 percent failure-to-appear rate on jury summonses, and my untested observation for the difference between the make-up of the people summoned and the make-up of the people on the venires is that blacks, Hispanics, young people, and men may be somewhat more likely to disregard their summonses than their race, ethnic, age, and gender counterparts.

I am also well aware that my judicial experience is in a region without an explicit segregationist tradition, and that that tradition seems still quite important in terms of the use and abuse of the peremptory challenge. It is disturbing, though not entirely surprising, that over the seven-year period from 1986 to 1993, the number of reported cases in which Batson challenges have been litigated are highest (not only on a per capita basis but in some instances even in raw numbers) in the southern and border states. Melilli, 71 Notre Dame L Rev at 466-70 (cited in note 2). Texas boasts a nation-leading 96 reported Batson cases in this period; significantly smaller Alabama reported an astounding 92; Missouri 58; Georgia 51; Louisiana 49. By contrast, there were only 47 reported Batson cases in all of New York state in this same period; 24 in California. Id at 467.
} 
are rampant not only with seething anti-defendant bigotry but with the kind of seething anti-defendant bigotry that is smart enough to disguise itself from the glare of the challenge for cause, the practice of giving equal numbers of peremptory challenges to each side actually increases, not decreases, the chances that these smart bigots will end up on the jury. This is so because any given peremptory challenge is more valuable to the prosecution in ferreting out those hypothetically few pro-defense jurors than it is to the defense, who will use up all its challenges and still tend to be left with some of those hypothetically rampant proprosecution jurors. ${ }^{193}$ Perhaps this is why, in an informal survey of the lawyers who practice in my courtroom, the prosecutors seemed substantially more vigorous in their defense of the peremptory challenge than the defense lawyers. ${ }^{194}$ Perhaps this is

\footnotetext{
${ }^{193}$ For example, let us assume a venire of one hundred made up of eighty proprosecution people and twenty pro-defense people. If we assume a "strike" system, see note 205, and that a panel of twenty-five is selected to be tested for cause and then subjected to peremptory challenges, the panel will on the average consist of twenty proprosecution people and only five pro-defense people. The prosecution will theoretically be able to exercise peremptory challenges to eliminate all pro-defense people from the jury. Of course, substituting "white" for "pro-prosecution" and "black" for "pro-defense," is precisely how the peremptory challenge was used for two hundred years in the American South to eliminate all blacks from juries. See text accompanying notes 96-111.

There is a nuance this hypothetical ignores, and that others have called in a more general context the principle of asymmetry: because a hung jury is ordinarily considered a victory for the defense, one pro-defense juror has significantly more value to the defense (and is correspondingly more dangerous to the prosecution) than a pro-prosecution juror has to the prosecution. The prosecutor needs to exclude all pro-defense jurors before he or she can obtain a victory; the defense lawyer only need sneak in one pro-defense juror to achieve a hung jury. This asymmetry justifies to some extent a more even distribution of peremptories than the above hypothetical suggests. Of course, this asymmetry is also just a small part of the more general asymmetric picture in a criminal case framed by the prosecution's burden of proof and the defendant's right to remain silent. That asymmetry formed the basis of some commentators' pre-McCollum arguments that Batson should not be extended to defense peremptories. See, for example, Goldwasser, 102 Harv L Rev at 811-20 (cited in note 2 ).

Of course, this hypothetical also ignores the fact, discussed in the text accompanying note 210, that it is a gross oversimplification to categorize jurors as pro-prosecution or pro-defense.

${ }^{19}$ When I asked one of the prosecutors in my courtroom what she thought of abolishing peremptory challenges, she responded, "Td rather get rid of challenges for cause." This comment is telling, not only because it expresses a level of commitment to the peremptory challenge, which I found almost universal among prosecutors, but also because it may well have been a way of expressing how the peremptory challenge is really just a lazy man's challenge for cause, much as it once was a lazy King's challenge for cause. See text accompanying notes 173-78. I also found it quite interesting that of the nine prosecutors whom I informally surveyed, only three expressed any sympathy at all with the idea of abolishing peremptory challenges, and each of those three handles complex prosecutions, many of which originate in the grand jury. In Colorado, the grand jury is selected without any peremptory challenges. Two of the three prosecutors inclined toward abolishing peremptory challenges based their views at least in part on their favorable experiences in picking and then working with grand jurors selected without the benefit of per-
} 
also why, for most of the history of the peremptory challenge, in both England and America, the defense customarily has enjoyed substantially more peremptory challenges than the prosecution. ${ }^{195}$

\section{THE PEREMPTORY CHALLENGE Is INCONSISTENT WITH FUNDAMENTAL PRECEPTS OF AN IMPARTIAL JURY}

If it were just that changing social, cultural and even constitutional conditions have made peremptory challenges obsolete, one could argue that their abolition is unnecessary. But they are not just obsolete. Especially now, in their post-Batson mutated form, peremptory challenges conflict with the most basic notions of individual liberty and individual responsibility inherent in the idea of trial by an impartial jury.

I came to this conclusion in a sort of extended epiphany during the course of my most recent tour of duty in a criminal division. During a streak of particularly serious cases, I gave the prospective jurors my usual introductory remarks, which include an overview of the selection process. In front of all of these prospective jurors, all of whom were rapt with the attention and seriousness of an impending murder or rape trial, I heard myself explain to them what I always explain-that we will go through a series of procedures to make sure they can be fair, we will eliminate those whom I determine cannot be fair, and then, after we are left with a panel of fair people, the lawyers get to eliminate some of those fair people without having to say why.

When one actually must explain this process out loud, it starts to make less and less sense, especially when one must do so in front of a group of citizens poised to embark on the most serious of civic endeavors, and who desperately want the process to make sense. In ruminating about my discomfort, I have come to the conclusion that there are three separate but related reasons why the whole concept of a peremptory challenge conflicts with basic notions of an impartial jury: (1) the peremptory challenge reflects an inappropriate distrust of prospective jurors; (2) it improperly shifts the focus of jury selection from individuals to groups; and (3) it injects an inappropriate level of adversariness into the jury selection process.

emptory challenges.

${ }^{195}$ See text accompanying notes 59-65 and 83-91. 
A. The Peremptory Challenge Reflects an Inappropriate Distrust of Jurors

The most obvious, and in some ways most important, dimension of the problem of the peremptory challenge is that it reflects a deep distrust of prospective jurors wholly inconsistent with the trust we repose in sitting jurors. We call citizens to jury duty with the stick of a summons and the carrot of high-minded appeals to their civic duty, but then we pass over great numbers of them for no reason at all. ${ }^{196}$ We tell them we want fair jurors, and that we have sophisticated mechanisms in place to separate the fair from the unfair, but then we suggest that these mechanisms are not only imperfect, but so imperfect that we guess that anywhere from 60 to 80 percent of them who pass muster for cause are actually holding hidden biases that our fancy questions cannot detect. ${ }^{197}$ We give them an oath to tell the truth, but then suggest we think most of them will lie. We tell them the case must be decided based solely on the facts presented and the law on which they are instructed, but then suggest few of them will be able to do so.

Perhaps this mistrust is well-founded, and perhaps the tension between the challenge for cause and the peremptory challenge is just one facet of the same Hobbes/Locke ambivalence that runs throughout the jury concept and indeed throughout the premises upon which our democracy was founded: There is enough good in the average person to have confidence he will render the right verdict (or elect the right official), but enough evil in him to suspect otherwise.

Still, even if the peremptory challenge is viewed as a kind of check and balance to the confidence we repose in jurors, the balance seems terribly skewed. Perhaps one or two peremptories in the odd case would, as in the English tradition, represent an adequate safeguard against the prospective juror who is the secret Klansman or the closet anarchist. But the American strain of peremptory challenges conveys to jurors a cynical and wholly exaggerated view of the extent to which we are teeming with perjurers and bigots, especially considering the great confidence we repose in jurors the moment they are seated and sworn, and

\footnotetext{
${ }^{196}$ See text accompanying notes 205-06.

${ }^{197}$ In noncapital federal cases, a total of sixteen peremptory challenges are available to select a jury of twelve. FRCrP 24(b). Assuming a strike system, see note 205, this means that of the twenty-eight jurors who are passed for cause and who form the pool against which peremptories are to be exercised, we think up to sixteen (or 57 percent) may have hidden biases. This "bias index" increases to 77 percent in capital cases, where a total of forty peremptory challenges are available.
} 
the even greater, almost unassailable, confidence we repose in their ultimate judgment. ${ }^{198}$

We even place significantly more trust in judges than in prospective jurors. We expect judges to be impartial arbiters of the law, and jurors to be impartial arbiters of the facts, yet who among us would condone an institutionalized system of judge shopping, where each side has some veto power over which judge presides over a case ${ }^{199}$ Instead, we are content that as long as a judge does not violate relatively objective standards that would require him or her to recuse, ${ }^{200}$ the judge can continue on a case despite any hidden biases. We should be no less trusting of our citizen-jurors. ${ }^{201}$

\footnotetext{
${ }^{153}$ Professor Alschuler has criticized the stark difference between, on the one hand, the lack of confidence we repose in jurors at the front end of the trial during jury selection, and in the middle of the trial with paternalistic rules of evidence, and, on the other hand, the almost unassailable confidence we repose in jury verdicts by way of the doctrine of judicial review. Alschuler, $56 \mathrm{U}$ Chi L Rev at 211-18, 232 (cited in note 1). Although I share some of Professor Alschuler's concerns, I am not so troubled by a system whose component parts offer a set of arguably inconsistent principles designed in some rough fashion to reflect our ambiguity about the nature of man, as I am with the single component of the peremptory challenge, which is internally inconsistent and inappropriately skewed toward distrust.

${ }^{199}$ This rhetorical questions turns out not to be so rhetorical. Nineteen states currently have some statute and/or rule giving litigants a one-time option to remove the assigned judge, without cause. For a listing of these states, and citations to the rules and statutes, see United States v Escobar, 803 F Supp 611, 614 (E D NY 1992). Although there were sporadic efforts in the 1970s and 1980s to extend this concept to the federal courts-both nationwide in proposed legislation and in some circuits and districts by local rule-those efforts all failed, after intense criticism. See generally id at 614-15; John R. Bartels, Peremptory Challenges to Federal Judges: A Judge's View, 68 ABA J 449, 450-51 (1982) (arguing against applying peremptory challenges to judges); Edward G. Burg, Comment, Meeting the Challenge: Rethinking Judicial Disqualification, $69 \mathrm{Cal} \mathrm{L}$ Rev $1445,1469-80$ (1981) (comparing the peremptory challenge system with existing law on disqualification); Alan J. Chaset, Disqualification of Federal Judges by Peremptory Challenge 41 (Fed Jud Ctr 1981). In 1992, despite the absence of any federal statute or rule authorizing peremptory challenges of federal judges, Judge Jack B. Weinstein, acting in his capacity as Chief Judge of the Eastern District of New York, announced a rule allowing all defendants in capital cases in that district to peremptorily challenge the first judge assigned to the case. Escobar, $803 \mathrm{~F}$ Supp at 618 . Judge Weinstein specifically reserved the issue of whether the prosecutor in such cases should have a similar right. Id at 620 . Tve found no other example of any judge-created system of peremptory challenges to judges.
}

${ }^{2 \%} 28$ USC $\$ 144$ (1994) provides in pertinent part:

Whenever a party to any proceeding in a district court makes and files a timely and sufficient affidavit that the judge before whom the matter is pending has a personal bias or prejudice either against him or in favor of any adverse party, such judge shall proceed no further therein, but another judge shall be assigned to hear such proceeding.

${ }^{201}$ If we accepted the democratic rhetoric of the jury system, we would select juries so that they reflected the breadth of our communities rather than the group left over when lawyers had expended their peremptory challenges based on pet hates. Accepting the premises of the jury system would mean viewing jurors neither as child 
In expecting so little from our jurors, perhaps we sometimes get what we deserve. Even the most enthusiastic defender of the peremptory challenge must acknowledge that it is not perfect, and that hidden biases will slip past the most masterful trial lawyer. I worry about the message we are sending to that inevitably biased juror: "Go ahead, act on your bias. We are all biased, and none of us can resist acting on those biases. So go ahead and act on yours. After all, you passed the test of peremptory challenges."

I worry even more about the message we are sending to the vast numbers of prospective jurors who are challenged peremptorily yet who hold no hidden biases, and who one day will return as prospective jurors in other cases: "No, I can't say exactly what it is about you that I don't like. But the slope of your brow or the cut of your clothes or the manner of your walk all tell me you are a lying bigot." What do these false allegations about the fairmindedness of prospective jurors do to their confidence in a system whose whole function is to unearth the truth? If we are so incompetent at distinguishing a fair juror from a bigot, what hope is there that we can distinguish a witness's lies from a witness's truths, or guilt from innocence?

Judge Broderick has articulated this concern eloquently:

The peremptory [challenge] is a renegade in this nation's trial procedures. . . . [P] eople will accept the decrees of courts only so long as the institution is perceived to be both unbiased and governed by the "quiet rationality" that is its distinction. It uses reason to confront disputes that are some of the most intractable, frightening, and emotion-laden that society has to offer. In the courtroom, the dispassion of the rule of law ideally answers hysteria and rumor. Every accusation or idea is tested by discourse and evidence. The logic of the court's decision-making is laid bare to the litigants, other judges, scholars, the media, and the community. The trial itself must unfold in public view.

savants nor as child simpletons but as responsible adults. It would mean abandoning our cumbersome, patronizing rules of evidence and trusting jurors with the facts. It would mean respecting the jurors' privacy, abandoning our probing of their psyches, beliefs, and practices in extended voir dire examinations. It would mean permitting prospective jurors to serve on juries unless, after asking only the questions needed to uncover interests and biases that would equally disqualify professional judges, grounds for their recusal appeared.

Alschuler, $56 \mathrm{U}$ Chi $\mathrm{L}$ Rev at 232 (cited in note 1). 
In contrast stands the peremptory challenge. It functions as a repository of the unexamined fears, suspicions, and hatreds held by attorneys and their clients. With the few exceptions now interposed by courts, the peremptory is exercised secretly, for any or no reason at all, unchecked by inquiry or debate. ${ }^{202}$

This is not simply a theoretical problem. Even if one assumes that some prospective jurors have hidden biases that can be detected and eradicated by peremptory challenges, the removal system is grossly overinclusive. In my experience, most people challenged peremptorily are truly challenged for no reason at all. There is a tremendous psychological pressure for lawyers on both sides to exercise some peremptory challenges. I have never witnessed a trial in which each side did not exercise at least half of the allowed peremptory challenges, and in my experience it is a relatively rare case in which both sides do not exhaust their full complement of peremptory challenges. ${ }^{203}$ Lawyers have a significant procedural incentive to exercise all of their peremptory challenges: if they do not, in most jurisdictions they lose any appellate argument regarding erroneous rulings on challenges for cause. ${ }^{204}$ In fact, if a lawyer is satisfied with the jury but has not exercised all peremptories, it is a well recognized tactic to continue to exercise all remaining peremptories by challenging the prospective jurors seated in the designated alternate seat, thus exhausting all peremptories without changing the

\footnotetext{
${ }^{5 \times 2}$ Broderick, 65 Temple L Rev at 417-18 (cited in note 2) (citations omitted).

${ }^{23}$ Indeed, in the method that I use, and that I believe most of my Colorado colleagues use, to select civil juries, there is no so-called "presumptive" jury, and each side must exercise all of its peremptory challenges.

" ${ }^{2}$ See, for example, United States v Torres, 960 F2d 226, 228 (1st Cir 1992); United. States v Hardy, 941 F2d 893, 897 (9th Cir 1991); People v Macrander, 828 P2d 234, 246 (Colo 1992); People v Daniels, 172 IIl 2d 154, 665 NE2d 1221 (1996); State v Mitchell, 674 S2d 250, 254 (La 1996); Degarmo v State, 922 SW2d 256, 262-63 (Tex App 1996). But see, at one extreme, cases like Ross, discussed in the text accompanying notes 162-72, suggesting that even if a defendant "preserves" the argument that he or she was forced to use a peremptory challenge by the erroneous denial of a challenge for cause, any such error is harmless unless it can also be shown that the resulting jury was not impartial. Accord United States $v$ Annigoni, 57 F3d 739, $744-45$ (9th Cir 1995); State $v$ Russell, 917 P2d 557, 560 (Utah Ct App 1996). At the other extreme, there are many cases that suggest, even post-Ross, that such error remains a ground for per se reversal, at least when one is talking about a direct interference with a defendant's right to exercise peremptory challenges (for example, by way of an erroneous Batson ruling) as opposed to an indirect interference (by way of an erroneous ruling on a challenge for cause). See, for example, United States $v$ Ricks, 776 F2d 455, 460-61 (4th Cir 1985) (granting a new trial because exercise of peremptory challenges were used on those not even considered for jury selection); United States $v$ Broussard, 987 F2d 215, 221 (5th Cir 1993) (distinguishing between erroneous rulings on challenges for cause because of peremptory challenges, and erroneous rulings on peremptory challenges themselves).
} 
identity of the jurors who will actually decide the case. ${ }^{205}$ Finally, of course, peremptory challenges are quite often exercised not to exclude a seated prospective juror, but rather to include an as-yet unseated prospective juror. ${ }^{208}$

The net effect of all of this is that perfectly acceptable, perfectly fair and perfectly impartial prospective jurors are being excluded in droves, and they are leaving our courthouses with a justifiable frustration and cynicism about our system.

I also worry about the mixed messages we send on the effect of bias. Lawyers and judges pay lots of voir dire lip service to the notion that although we are all biased in some ways, many of us can set those biases aside. That is an important, noble and, I believe, accurate proposition. Indeed, it is one of the principles behind the very notion that when twelve people decide a case the sharpest edges of their individual biases will get rounded-off by the deliberative process. Our system of peremptory challenges, on the other hand, substantially devalues both the ability of jurors to set those biases aside and the curative effect of deliberation. Peremptory challenges tell these prospective jurors that they all have biases much worse than they will own up to (or, perhaps, are even conscious of), and that most of these biases are debilitating and will prevent them from being fair even if they think they can set them aside. This perception denies the reality that biased jurors can indeed set aside their biases in order to judge impartially. This is what deliberation is all about. ${ }^{207} \mathrm{In}-$

\footnotetext{
${ }^{25}$ This tactic works when peremptory challenges are exercised by the so-called "strike" method: a panel of prospective jurors is called up at random from the entire venire, equal in number to the number of jurors plus alternates that will be needed, plus the total number of peremptories; the panel is then examined; challenges for cause are then exercised only to the panel; replacement panelists are seated and examined; and then the peremptories are exercised, again only to the panel. The other basic method of exercising peremptory challenges is called the "sequential" or "jury box" method, in which the entire venire is examined before any prospective jurors are called up, and peremptory challenges are exercised as the prospective jurors are called up at random to be seated. The significant difference between these two methods is that in the strike system the lawyers know, as they are exercising their peremptories, which prospective juror will be replacing the person who is peremptorily challenged. For two good descriptions of these two methods see Gurney, Note, 21 Harv CR-CL L Rev at 227-28 (cited in note 2), and Leonard B. Sand, Batson and Jury Selection Revisited, 22 Litigation 3, 3-4 (Summer 1996).

${ }^{206}$ Again, this tactic works in the strike method but not in the sequential method. See note 205.

${ }^{207}$ An English barrister has expressed surprise at how little the American system trusts jurors' abilities to be impartial despite their biases:

I think if I knew what the backgrounds of the jurors were ... I still wouldn't challenge them. I don't think I would be able to handle the American system, actually ... because I happen to take the view that whatever one's personal prejudices, the chances are that a juror called to jury service and knowing the weight and responsi-
} 
deed, the very presence of an opposing bias, or of a juror who is a member of a group that is the object of such bias, can aid in suppressing the expression of that bias in the verdict. ${ }^{208}$ In any event, and not surprisingly, empirical studies show that lawyers are no better at predicting the way biases might be expressed in verdicts than they are in detecting bias itself. ${ }^{209}$

Finally, and most fundamentally, peremptory challenges reflect an astoundingly simplistic view of the whole nature of human bias. They trivialize the way in which we are all biased in some sense and over a wide spectrum. Professors Zeisel and Diamond have described the complexity of juror bias this way:

All jurors' experiences have shaped their values and attitudes, and these, in turn, are likely to shape jurors' perceptions of the trial evidence and hence their votes. In this sense, "prejudice" is not only ineradicable but often indistinguishable from the very values and attitudes of the community that we expect the jurors to bring to the trial..$^{210}$

I am worried not so much that lawyers fool themselves into believing they actually can ferret out hidden biases, as I am with the demeaningly simplistic message this system sends to prospective jurors by presupposing that all people more or less fall into the two categories of biased and unbiased, or, even worse, into the two categories of biased for the prosecution and biased for the defense. In reality, of course, every juror brings with him or her a complex constellation of experiences that has produced a complex constellation of biases. It is only at the extreme where those biases coalesce into a particularly deep and strongly held viewpoint that they cannot either be set aside entirely at the jury room door or at least surrendered to the rational persuasion of fellow jurors.

By firing their simple peremptory challenge guns at the biased among us, lawyers are shooting us all, and the injuries are taking their toll on the public's confidence in the jury system.

bility upon him will do his utmost to discard prejudice.

Quoted in Hans and Vidmar, Judging the Jury at 49 (cited in note 77).

${ }^{279}$ See the studies cited in Marder, 73 Tex L Rev at 1082 (cited in note 2) (arguing that group deliberation promotes transparency in decisionmaking).

${ }^{2 ;}$ See id at 1080-81 nn $156 \& 157$.

${ }^{210}$ Zeisel and Diamond, 30 Stan L Rev at 531 (cited in note 6). 
B. Peremptory Challenges Improperly Shift the Focus of Jury Selection from the Individual to the Group

Our justice system is a temple to principles of individual responsibility. Every day, freedoms and money are sacrificed on the altars of that temple, and they are sacrificed to the axiom that we are all individuals with free will, and are all ultimately responsible for our individual actions. With only a very few exceptions, ${ }^{211}$ our laws at every stage of the process and in every conceivable context warn us that we will be held accountable for our individual actions, and comfort us that we will not be held accountable for the actions of others. Moreover, our temples are built on the foundation that rational inquiry into the facts of a case, limited by rules of evidence, can determine exactly what actions an individual took and what actions he should be held accountable for. How strange that the high priests in these temples-to whom the only constitutional command is to be impartial-are selected not for their observable individual traits but for supposedly hidden traits inferred from their membership in various identifiable groups.

The logical unit of jury impartiality is the individual juror, not real or imagined coalitions of jurors who share the same skin color, gender, political views or social standing. Partiality, and therefore impartiality, inheres in the character of each individual juror:

Jury competence is an individual rather than a group or class matter. That fact lies at the very heart of the jury system. To disregard it is to open the door to class distinctions and discriminations which are abhorrent to the democratic ideals of trial by jury. ${ }^{212}$

To be sure, it can be a complex, time-consuming, and incomplete process to inquire into the individual characteristics of prospective jurors. But neither the difficulty nor inherent imprecision of that effort justifies its abandonment to the crass prejudices of group stereotyping.

By giving lawyers the power to veto prospective jurors for no reason at all, we of course give them license to act on the basest of human prejudices. But the problem of de-individualizing the jury selection process is much deeper than a handful of, or even a nation full of, racist and sexist lawyers. By relying not only on

\footnotetext{
${ }^{211}$ The doctrines of complicity and, to a lesser extent, conspiracy come to mind.

${ }^{212}$ J.E.B., 511 US at 145-46 n 19, quoting Thiel $v$ Southern Pacific Co, 328 US 217, 220 (1946).
} 
skin color or sex, but also on a universe of other surface characteristics from which they believe they can detect hidden biases, lawyers are making crass and, by definition, unjustifiable generalizations about large classes of jurors. In this sense, the proposition that black jurors will not convict a black defendant is no more offensive than the proposition that jurors who wear pocket protectors are pro-prosecution. ${ }^{213}$ Neither our rules of evidence nor even our most basic ideas of due process tolerate such preposterous propositions, and it is amazing that we tolerate them in jury selection.

Professor Melilli has quantified, in a manner of sorts, the extent to which these baseless generalizations figure into the exercise of the peremptory challenge. He examined all reported cases from the date Batson was announced in 1986 through 1993, and concluded that an astonishing 52 percent of all those peremptory challenges involved what he characterized as a "group stereotype." 14 These stereotypes ranged from the not-so-exotic "prior criminal activity" to such ridiculous examples of prejudice as "from Texas," "inner city person," "from New York," and my personal favorite, "prior jury service."215 Professor Melilli summarized his findings with this rhetorical suggestion:

The reader can, of course, examine [these results] and form his or her own conclusion about whether lawyers are truly serving their clients' interests by removing these groups of venirepersons, or whether the whole business of striking people from participation on the jury on these grounds is at the least silly, if not offensive. ${ }^{216}$

The problem of group moneychangers in the temples of individuality is not an abstract one. Every time a prospective juror is peremptorily challenged we are telling that prospective juror that the foundation of this system is not evidence, but rather rumor, innuendo, and prejudice. ${ }^{217} \mathrm{I}$ cannot count the number of times I have seen prospective jurors flash me a look of betrayal when, after they have passed through the gantlet of challenges for cause, they have been excused peremptorily because of their

${ }^{213} \mathrm{~A}$ friend of mine who was a chief prosecutor for over ten years once confided this peculiar piece of prosecutorial folk wisdom to me. He admitted a few years later that he needed to revise this rule when one of his pocket-protector jurors was a holdout for acquittal. The elusively malleable nature of these untestable folk wisdoms seems to be their most reliable feature.

14 Melilli, 71 Notre Dame L Rev at 497 (cited in note 2).

${ }^{215}$ Id at $497-98$.

${ }^{215}$ Id at 499.

${ }^{217}$ See text accompanying notes 196-206. 
educational level or their occupation or the kind of car they drive. ${ }^{218}$ Is it any wonder that these people leave our courtrooms thinking that the whole trial process is just as trivial and flawed as jury selection?

Some commentators have actually argued that the unstated irrationality of the peremptory challenge is a strength, not a weakness. These commentators suggest that by hiding the irrationality of bigotry and other group prejudice in the cocoon of the peremptory challenge, the system benefits by not having to "trade" explicitly in these embarrassing issues. ${ }^{219}$ I suggest these

\footnotetext{
${ }^{218}$ Some of the more cynical trial lawyers to whom I have mentioned this observation have expressed surprise and doubt, believing that all prospective jurors have as their prime goal to be excused from jury service by hook or crook. Of course, I sometimes see these kinds of people, but substantially more often I see prospective jurors who either want very much to serve, or, at the very least, accept their obligation to serve with the kind of valiant resignation akin to most citizens' views about the obligation to pay taxes. My experience is that most prospective jurors take their roles very seriously, at least by the time we have reached the peremptory challenge phase, and I sense they are regularly offended when they are excused for unexplained reasons, about which they naturally assume the worst.

${ }^{219}$ See, for example, Barbara Allen Babcock, Voir Dire: Preserving "Its Wonderful Power", 27 Stan L Rev 545, 553-54 (1975):

The peremptory, made without giving any reason, avoids trafficking in the core of truth in most common stereotypes. ... [W]e have evolved in the peremptory challenge a system that allows the covert expression of what we dare not say but know is true more often than not.

I honestly cannot comprehend what "core of truth" Professor Babcock thinks is locked inside the stereotypes that drive most peremptory challenges. Stereotypes seldom become stereotypes because they are true. Most are simply temporary cultural expressions of the irrational fears all humans have of the unknown-of different races, of different places, and of different viewpoints. If one had any doubt at all about the "core of truth" in these stereotypes, one need only look back at the stereotypes of yesteryear. In a famous trial handbook quoted by Justice Marshall in his Batson concurrence, Dallas prosecutors were trained not to take "Jews, Negroes, Dagos, Mexicans or a member of any minority race on a jury, no matter how rich or how well educated." 476 US at 104 n 3 (Marshall concurring) (citation omitted). In yet another notorious example of lawyer folk wisdom, Clarence Darrow once advised that women should be avoided in all defense cases, and that "Presbyterians are too cold; Baptists are even less desirable. . . [K] [eep Jews, unitarians, Congregationalists, and agnostics." Quoted in James Morton, Jury Selection, 137 New L J 561, 562 (1987). Finally, celebrity lawyer Melvin Belli had these misogynisms to share about the role of women on juries:
}

If the plaintiff is a woman and has those qualities which other women envy-good looks, a handsome husband, wealth, social position-then women jurors would be unwise. Woman's inhumanity to woman is unequalled. They are the severest judges of their own sex.

Women ... are desired jurors when plaintiff is a man. A woman juror may see a man impeached from the beginning of the case to the end, but there is at least the chance the woman juror (particularly if the man happens to be handsome or appealing) that [sic] the plaintiffs derelictions in and out of court will be overlooked. A woman is inclined to forgive $\sin$ in the opposite sex; but definitely not in her own. 
commentators would quickly be disabused of this notion by spending some time watching lawyers in voir dire ask prospective jurors about their television-watching habits, their magazine subscriptions, and their theories on toilet-training. The proposition that lawyers, in the exercise of their peremptory challenges, are permitted to act, and indeed are often acting, on their most base, bigoted, stereotyped, and irrational hunches screams out to everyone present during voir dire. We are not fooling anyone, except apparently a few law professors, by refusing to shine the light of rational inquiry on these insupportable hunches.

Of course, Batson has greatly exacerbated this problem of de-individualizing the jury selection process, by so paternalistically insisting that peremptory challenges be screened for any hint of impermissible group bias. Batson teaches us that some irrational stereotypes are constitutionally permissible, and some are not. We implicitly give institutional approval to those innumerable hunches that do not happen to touch upon the untouchable areas of race, ethnicity, or sex. We encourage lawyers to tell us they did not excuse Mr. Jones because he was black, but rather because he was a Gemini.

In our relentless post-Batson hunt for lawyers with the temerity to act on those particular irrational hunches that are deemed constitutionally impermissible, we of course must traffic in an inquiry whose very coin is group composition. Chief Justice Burger criticized this kind of de-individualizing in his Batson dissent:

A further painful paradox of the Court's holding is that it is likely to interject racial matters back into the jury selection process ... . Today we mark the return of racial differentiation as the Court accepts a positive evil for a perceived one. Prosecutors and defense attorneys alike will build records in support of their claims that peremptory challenges have been exercised in a racially discriminatory fashion by asking

Melvin M. Belli, Sr., 3 Modern Trials $\$ 51.68$ (West 2d ed 1982). Exactly what is the "core of truth" in these stereotypes?

To be fair to Professor Babcock, she has candidly retreated from her "core of truth" suggestion and from her unabashed enthusiasm for peremptory challenges:

What I failed to recognize, however, was that, even though no words were spoken, tides of racial passion swept through the courtroom when the peremptory challenges were exercised. Everyone could see what was happening .... Perhaps the silence harbored thoughts worse than those that might have been said.

Barbara Allen Babcock, A Place in the Palladium: Women's Rights and Jury Service, $61 \mathrm{U}$ Cin L Rev 1139, 1147 (1993). However, Professor Babcock maintains her position that peremptory challenges can be both effective and constitutional, provided they are coupled with other jury selection reforms. Id at 1174-80. 
jurors to state their racial background and national origin for the record . ... . ${ }^{220}$

Lawyers and judges are now forced to engage in a kind of amateur anthropology-categorizing the race and ethnicity of the prospective jurors and arming themselves with their versions of the official bean count in anticipation of the inevitable Batson challenge. This amateur anthropology is not only institutionally embarrassing, it is unspeakably intrusive to prospective jurors. Judges should not have to decide whether Ms. Fujimoto-Gonzalez is an Hispanic, an Asian, or an Aleutian Islander. I cannot imagine a more distasteful, irrelevant, undemocratic, or damaging line of inquiry.

If all that were not enough, judges are on notoriously thin ice when we engage in this amateur anthropology. Even before Batson, there have been spectacularly ridiculous gaffes committed by judges when they put jurors into wrong ethnic or racial pidgeonholes. ${ }^{221}$ We can expect more of the same as long as Batson and peremptory challenges are both with us.

Batson has injected a new affirmative action twist into the racism and sexism of peremptory challenges. But neither malignant nor benign race, ethnic, or sex discrimination has any place in jury selection, and neither lawyers nor judges can, or should, focus their attention on the race, ethnicity, or sex of prospective jurors. By doing so, the real question-whether a particular individual juror can be impartial in a particular case-is getting lost in the anthropological shuffle.

The elimination of the peremptory challenge would invigorate our jury selection system with a long overdue dose of individuality. I heartily agree with Professor Marder's vision of a jury selection system in which the focus is on the individual juror's ability to be impartial, and not on membership in any group:

\footnotetext{
${ }^{220}$ Batson, 476 US at 129-30 (Burger dissenting) (citation omitted). In fact, however, and contrary to Chief Justice Burger's predictions in this regard, it has been my experience that lawyers never ask these racial or ethnic questions directly of the prospective jurors. Instead, they leave us judges to flounder in these dangerous anthropological waters completely untethered to any actual information on these issues, except what we can glean from the prospective jurors' names and appearances.

${ }^{221}$ In his dissent in Batson, Chief Justice Burger discussed the case of People $v$ Motton, $39 \mathrm{Cal} 3 \mathrm{~d} 596,217 \mathrm{Cal} \mathrm{Rptr} 416$ (1985), in which Mr. Motton's conviction was reversed on appeal because there were no blacks on the jury. In fact, however, there was a black woman on the jury, who contacted the press with some degree of surprise when she read of the reversal and of the erroneous reports of her own race. 476 US at 130 (Burger dissenting).
} 
My understanding of "impartial" would require the Court to put into practice what it has long expressed in case law: prospective jurors are to be judged on an individual basis and no prospective juror should be excluded because of an immutable characteristic. . . . I would ... start with the premise, as courts do in England, that all prospective jurors who meet the statutory criteria are competent to serve. Some may still be excluded from the petit jury for cause either because they are related to the parties, because they are connected to the litigation, or because they enter with a closed mind and believe they cannot be impartial. We should start, however, with the view that is deeply embedded in our democratic society that people will be judged as individuals and will not be presumed to be unfit to serve as jurors because of some stereotypical notion about their group identity. ${ }^{222}$

C. The Peremptory Challenge Injects an Inappropriate Level of Adversariness into the Jury Selection Process

By this I do not mean that peremptory challenges give the lawyers a chance to be nasty to each other during voir dire, though they certainly do that. ${ }^{223}$ I mean that the goal of jury selection is to end up with twelve fair jurors, and the use of peremptory challenges tends instead to result in juries with six proprosecution jurors and six pro-defense jurors. ${ }^{224}$ Two sets of partial jurors do not an impartial jury make.

This balkanization of the jury happens because of the way peremptory challenges mesh, or do not mesh, with the other parts of jury selection. The idealized model of the peremptory challenge views bias as a rather simple condition distributed normally, that is, in bell-curve fashion, over the general population. In this model, the most extreme pro-prosecution jurors are excused peremptorily by the defense, and the most extreme prodefense jurors are excused peremptorily by the prosecution, leaving jurors somewhere in the middle of the bell curve. This is the so-called "leveling effect" touted by many supporters of the

${ }^{2}$ Marder, 73 Tex L Rev at 1133-34 (cited in note 2) (citation omitted).

${ }^{20}$ When one lawyer makes a Batson challenge, he or she is in effect calling the other lawyer a bigot, and when a prima facie case is made out, a neutral reason proffered, and the neutral reason resisted, the name calling accelerates from bigot to liar. We therefore litigate these issues in an atmosphere almost always devoid of any remnants of civility and professionalism.

${ }^{24}$ But of course it is a gross oversimplification to label jurors this way. See text accompanying note 210 . Also, this model assumes an equal distribution of pro-prosecution and pro-defense jurors in any given venire. But see text accompanying notes 193-95. 
peremptory challenge. ${ }^{225}$ But this model ignores the relationship between peremptory challenges and challenges for cause, ignores the complexity of the bias inquiry, ignores a kind of feedback effect in which the very process of voir dire may actually cause impartial jurors to become partial, and ignores the detrimental impressions which this process leaves on prospective jurors who are excused.

The most "extreme" prospective jurors are of course eliminated during challenges for cause, after a justifyingly adversary process. The prospective jurors who are passed for cause have survived those adversary fires, and therefore already lie, at least by any objective measure, in the center of the bias bell curve. At the very least, then, the supposed leveling effect of a handful of peremptory challenges is grossly exaggerated because the venire has already been leveled by an unlimited number of challenges for cause. ${ }^{226}$

In fact, as a result of having to make very discrete and indeed binary decisions about the very non-discrete and complex problem of human bias, lawyers' oversimplified voir dire runs a great risk of driving otherwise neutral prospective jurors into pro-defense or pro-prosecution camps. This is a particularly virulent strain of the "go-ahead-and-act-on-your-bias" disease discussed above. ${ }^{227}$ Otherwise impartial jurors who are constantly bombarded in voir dire with questions accusing them of being secret agents for the prosecution or secret agents for the defense may very well feel compelled to join one of those mind-sets.

Even if peremptory challenges do not in fact result in the balkanization of juries, they create the unmistakable impression that balkanization is the goal. Prospective jurors who go through the process-and especially those who are in great numbers excused even though they have no bias ${ }^{228}$-are given the distinct impression that the prosecution will "pick" six pro-prosecution jurors and the defense will "pick" six pro-defense jurors. ${ }^{229}$ This perception of a balkanizing process inflicts just as much institu-

\footnotetext{
${ }^{25}$ For example, the Swain Court itself described one of the functions of the peremptory challenge to be "to eliminate extremes of partiality on both sides." 380 US at 219 .

${ }^{226}$ But see text accompanying notes $230-35$, arguing that the peremptory challenge has an extreme effect on the composition of the jury itself, as distinguished from its modest effect when looking at the entire venire.

${ }^{2}$ See text accompanying notes 201-02.

${ }^{223}$ See text accompanying notes 202-06.

${ }^{20}$ I have seen a few brave lawyers in my courtroom-usually prosecutors-actually ask prospective jurors during counsel's voir dire what they, the jurors, think the lawyers are trying to accomplish in voir dire. We get a lot of "trying to pick fair jurors," but a surprisingly large number of "trying to find jurors favorable to one side or the other."
} 
tional damage in lost public confidence as actual balkanization does. Indeed, perceived balkanization can be much more damaging, because many more prospective jurors are excused than serve, and those excused prospective jurors leave the process before they can see who actually ends up on the jury. And, of course, they never deliberate and therefore never get to experience firsthand the fact that most jurors are not biased, or the fact that even those who are biased can put their biases aside and accede to the rational persuasion of their co-jurors during deliberations. Instead, the excused, non-biased venireperson leaves thinking that he or she was excused precisely because he or she was not biased, and therefore that the entire purpose and goal of this adversary selection process was to find two equal groups of oppositely-biased jurors.

Finally, even ignoring real and perceived balkanization, there are good arguments that the "leveling effect" is itself inconsistent with basic notions of juror impartiality. First, it is not at all clear what it is we are trying to "level." The conventional theory is that peremptory challenges level the venire's tendency to be partial, ${ }^{230}$ but critics would argue and have argued that what is actually being leveled is the very diversity guaranteed by the fair cross-section requirement of the Sixth Amendment. ${ }^{231}$ The problem has its roots in simple arithmetic, and in the fact that statistically significant notions like "fair cross-section" lose their meaning when we move from a large population like the venire to a very small population like the jury itself. In this sense, the Court in Holland $v$ Illinois $^{232}$ was perfectly correct in refusing to extend the fair cross-section requirement from the venire to the jury. It cannot be seriously contended that a defendant has a right to insist that the twelve jurors who actually hear the case reflect a fair cross-section of the community. When we are dealing with large numbers of summoned jurors, the samples are so large that they should be fairly representative of the community; if they are not, some discriminatory force may be at play. But juries are made up of only twelve people, and to require such a small sample to be "representative" has little statistical meaning. Instead, we recognize that in any given case, the unguided hand of fate may select from a perfectly representative venire an absolutely unrepresentative jury, and we accept that risk as the

\footnotetext{
${ }^{20}$ See note 225 and accompanying text.

a1 Marder, 73 Tex L Rev at 1063-66 (cited in note 2).

${ }_{2 \approx 2}^{2} 493$ US 474, 480-84 (1990). See note 125 and accompanying text.
} 
price we pay for not infecting the selection process with impractical and meaningless representational constraints. ${ }^{233}$

But it is one thing to accept the known risk that in any given case fate may mis-sample a representative venire, and quite another to permit the peremptory challenge to do so in virtually every case. Again, the problem is that we are dealing with a very small number of jurors. As we can see from the history of the peremptory challenge in this country, ${ }^{234}$ just a handful of peremptory challenges can result in the total exclusion of significant groups that were part of the fair cross-section. This "leveling effect" of the peremptory challenge is so massive that the fair cross-section requirement can lose all of its meaning. ${ }^{235}$

The English recognized that as their venires became more and more heterogeneous, peremptory challenges made less and less sense, because of their awesome power to distort that heterogeneity. Indeed, apart from the rhetoric surrounding the Cyprus spy trial, ${ }^{236}$ the institutional reason most commonly advanced for the 1989 elimination of the English peremptory challenge was the increasing diversity of the English venire, and the threat to that diversity posed by the peremptory challenge. ${ }^{237}$

Another problem with the leveling effect is that it springs from an exaggerated view of the utility of the adversarial process in selecting juries. Our system already recognizes that jury selection, in contrast to the truth-finding process once the jury is selected, is simply not best accomplished in the pure fires of the adversary paradigm. Judges exert a substantial amount of unabashedly non-adversary control over jury selection. We welcome the prospective jurors to our courtrooms, we give them introductory instructions covering some basic legal principles, we tell them we want to try to find twelve impartial jurors, we con-

\footnotetext{
${ }^{230}$ To suggest that the jury itself must consist of a designated percentage of individuals belonging to cognizable groups brings to mind the ancient and long-abandoned English doctrine of "de medietate linguae." Under that doctrine, foreign merchants on trial in England in certain cases had a right to have one-half of their juries be made up of their own countrymen. $28 \mathrm{Edw} 3$, ch 13 (1354) (Eng); Blackstone, 4 Commentaries at *352 (cited in note 9). Needless to say, that bizarre doctrine did not survive our adoption of the Sixth Amendment. United States $v$ Woods, 299 US 123, 130 (1936); People v Vesely, 587 P2d 802, 806 (Colo Ct App 1978); Commonwealth $v$ Acen, 396 Mass 472, 487 NE2d 189, $191-92$ \& $n 7$ (1986).

${ }^{224}$ See text accompanying notes $96-111$.

${ }^{225}$ See Marder, 73 Tex L Rev at 1063-66, 1131-34 (cited in note 2).

${ }^{206}$ See text accompanying notes $66-67$.

${ }^{27}$ See, for example, John F. McEldowney, "Stand By for the Crown:" An Historical Analysis, 1979 Crim L Rev 272, 281-82. See also Samuel J. Cohen, The Regulation of Peremptory Challenges in the United States and England, 6 BU Intl L J 287, 313-14 (1988) (Parliament's primary rationale for eliminating the peremptory challenge was to preserve the "random nature of jury selection.").
} 
duct some preliminary voir dire, and indeed in most federal courts we conduct all of the voir dire. ${ }^{238}$ From the minute jury selection starts-interrupted only by that awkward moment when we tell them about the mysteries of the peremptory challenge $e^{239}$ - the unwavering message we send to prospective jurors is that this jury selection process is an objective effort to find twelve impartial jurors, with very little input from the advocates.

The proposition that twelve impartial jurors can best be selected by two sides intuitively vetoing those suspected of being the most partial, after all of them have already been determined to be impartial, is no more sensible than the proposition that each side should be able to select six jurors from the impartial venire. We no longer admit to this sort of trial by compurgation because we recognize that the ideal juror should no longer be a witness-with knowledge of the case, with loyalties to one side or another, and with extrinsic views about the litigants' credibility-but rather should be an impartial judge of the credibility of witnesses.

The very ideal of impartiality contains within it the principle that it is best achieved by some neutral power's application of objective criteria, and that is precisely the initial message we send when we go through the whole process of challenges for cause. After the advocates question the prospective jurors and are given an opportunity to argue, a neutral power, the judge, determines whether prospective jurors do or do not meet certain

\footnotetext{
223 For a survey of voir dire practices in the various states and federal districts, see V. Hale Starr and Mark McCormick, Jury Selection: An Attorney's Guide to Jury Law and Methods (Little, Brown 2d ed 1993). There has been some movement in Colorado, and I suspect similar movements elsewhere, to adopt in the state courts the general federal method of having judges conduct most or all voir dire, at least in criminal cases. In the spring of 1995, the Committee on Rules of Criminal Procedure recommended to the Colorado Supreme Court that our Rule 24 be modified to adopt the federal practice of judge voir dire supplemented with written questions from counsel. The recommendation was based on a survey of all 111 district judges in Colorado. There was a 70 percent response rate, and of those that responded, 73 percent supported the modification, 22 percent opposed it, and 5 percent had no opinion. Letter (with attachments) dated June 29, 1994 from District Judge Steven T. Pelican to Chief Justice Luis D. Rovira (on file with U Chi L Rev). After public hearings, the Colorado Supreme Court decided not to adopt the recommendation. Letter dated June 7, 1995 from Chief Justice Anthony F. Vollack to District Judges Steven T. Pelican and John N. McMullen (on file with U Chi L Rev). Although I share many of my colleagues' criticisms of the efficiency of counsel's voir dire, I do not agree that the solution is to have judges perform that function. The reason counsel's voir dire is so inefficient is that they must ask questions broad enough to "intelligently" exercise their peremptory challenges. There is no doubt in my mind that if peremptory challenges were eliminated, and voir dire questions were refocused on the issue of whether a juror could be fair and impartial, instead of on his or her ice cream eating habits, the waste we all see in counsel's voir dire would be curtailed greatly.

${ }^{2 *}$ See text accompanying notes 195-96.
} 
disqualifying conditions. But the peremptory challenge system is a kind of adversary process gone amok, unbounded by the checks of any neutral authority. Imagine any other adversary process where each advocate not only gets the customary opportunity to inquire, but then gets an alternating opportunity to decide all the issues, without even being required to articulate his decision. It might sound something like this:

Judge: Are counsel ready for peremptory decisionmaking?

Prosecutor: Yes, judge.

Defense lawyer: Yes, judge.

Judge: All right. There are four issues to be decided: (1) Whether Defendant shot Joe Victim; (2) Whether Defendant acted knowingly; (3) Whether Defendant acted in self-defense; and (4) Whether Defendant acted in the heat of passion. The People's first peremptory decision, please.

Prosecutor: Thank you, judge. The People respectfully decide as to issue 1 that Defendant did in fact shoot Joe Victim. please?

Judge: Thank you. Defendant's first peremptory decision,

Defense lawyer: Judge, the Defendant respectfully decides as to issue 3 that Defendant acted in self-defense.

Judge: All right. I don't need to elicit further peremptory decisions. A judgment of acquittal enters. ${ }^{240}$

We do not permit this sort of silly substantive game-playing because the whole system is designed to resolve these issues rationally, after logical presentation of and inquiry into all the facts. We do not complain that these are difficult issues incapable of being determined after rational inquiry, or that counsel's intuition should be the metric by which they are all to be measured. Instead, we try the case, and in doing so we retain some level of institutional confidence that our lawyers will be competent enough, and our impartial jurors smart enough, to separate the wheat from the chaff. We should do no less when we set about to select those impartial jurors.

\footnotetext{
${ }^{2 * 0}$ The defense won because it had two dispositive issues-whether Defendant killed the victim and whether Defendant acted in self-defense-and the prosecution could only knock out one of those two issues with its first peremptory. Obviously, such an irrational system would put a premium on the gamesmanship of the lawyers and their tactical ability to define the issues and maneuver them in an advantageous way. This is really just an extreme example of the current sideshow we call peremptory challenges.
} 


\section{CONCLUSION}

Peremptory challenges were born of irrational royal origins two hundred years before juror impartiality had any meaning. They enjoyed a spotty English history, suffered a shameful history in the United States, and were ultimately abandoned in England. Maybe none of this should be enough for us to abandon a tradition so old and so widespread. But even assuming the peremptory challenge ever worked in this country as anything other than a tool for racial purity, and even assuming it is working today in its post-Batson configuration to eliminate hidden juror biases without being either unconstitutionally discriminating or unconstitutionally irrational, I submit that its institutional costs outweigh any of its most highly-touted benefits. Those costs-in juror distrust, cynicism, and prejudice-simply obliterate any benefits achieved by permitting trial lawyers to test their homegrown theories of human behavior on the most precious commodity we have-impartial citizens.

At worst, these homegrown theories are our old friends racism, sexism, and class hatred all dressed up in twentieth century psychobabble, still stubbornly resistant to the most well intentioned fine-tuning of Batson. At best, they are animus-free nonsense, but nonsense nonetheless. In either case, the daily infliction of these theories on our citizen-jurors is exacting a palpable cost in lowered public confidence in the quiet rationality of our jury system. If we cavalierly let those institutional costs accumulate, and permit our quiet rationality to be drowned out by the cacophony of an irrational jury selection process, I am afraid that at some point the damage to the entire system may be irreparable. An American Cyprus spy trial may come along, ${ }^{241}$ but the right to a jury trial itself may be thrown out along with the peremptory challenge bath water.

\footnotetext{
${ }^{241}$ See text accompanying notes 66-67. Maybe the O.J. Simpson criminal case was our Cyprus spy trial, and maybe the peremptory challenge fallout from that case is yet to be fully felt.
} 
